Article

\title{
The Energy Saving Potential of Wide Windows in Hospital Patient Rooms, Optimizing the Type of Glazing and Lighting Control Strategy under Different Climatic Conditions
}

\author{
Silvia Cesari ${ }^{1,2}\left(\mathbb{D}\right.$, Paolo Valdiserri ${ }^{3, *} \mathbb{0}$, Maddalena Coccagna ${ }^{2}(\mathbb{1})$ and Sante Mazzacane ${ }^{2}$ \\ 1 Department of Architecture, University of Ferrara, 44121 Ferrara, Italy; silvia.cesari@unife.it \\ 2 CIAS Research Centre for Pollution Control in High Sterility Rooms, Department of Architecture, \\ University of Ferrara, 44122 Ferrara, Italy; maddalena.coccagna@unife.it (M.C.); \\ sante.mazzacane@unife.it (S.M.) \\ 3 Department of Industrial Engineering, University of Bologna, 40136 Bologna, Italy \\ * Correspondence: paolo.valdiserri@unibo.it; Tel.: +39-051-2093303
}

Received: 16 February 2020; Accepted: 21 April 2020; Published: 24 April 2020

check for updates

\begin{abstract}
If not properly designed, the adoption of large windows can sometimes have a negative impact on building energy demand. For this reason, aggravated by the outdated building envelope of the healthcare building stock, large fenestration systems are usually avoided in hospitals, especially in old structures. However, with appropriate glazing specifications, the adoption of wider openings can result into significant energy savings, lower costs and strong positive effects on patients and staff well-being. The present study investigates how different window sizes and types of glazing affect heating, cooling and lighting energy demand in a hospital patient room. The objective is to evaluate the energy savings that may be obtained when installing larger windows and to identify the glazing properties allowing one to reach the maximum energy reductions. Simulations were carried out using nine diverse glazing systems, already available on the market, and their energy performance was evaluated in relation to two different window areas: a common size opening, characterized by a 25\% Window-to-Wall Ratio (WWR), and a floor to ceiling window, with 77\% WWR. The analysis was conducted taking into consideration four different orientations in four Italian cities, supposing two artificial lighting control strategies. The results highlighted how the adoption of wider windows with appropriate glazings and a daylight-linked dimming lighting control strategy may lower the primary energy demand up to $17 \%$.
\end{abstract}

Keywords: energy demand; hospital patient rooms; window-to-wall ratio (WWR); glazing specifications; lighting; dynamic building energy simulations; TRNSYS

\section{Introduction}

Among the three macro-areas in which regulation and scientific literature distinguish hospital spaces [1-5]-Inpatient Units (IPUs), Diagnostic and Treatment Facilities (D\&T) and nonclinical spaces or general services-IPUs are characterized by less high-tech, energy intensive areas and medical equipment than D\&T Facilities.

However, albeit spaces for IPUs have been decreasing in favor of those occupied by general services, IPUs still represent a significant percentage of the conditioned floor area in old existing hospitals. Providing healthcare services 24/7, patient rooms are characterized by massive heating and cooling energy consumption, due to the necessity of high ventilation rates and their stricter requirements for microclimatic control. Furthermore, being located in the perimeter areas of the 
building to ensure maximum natural light, patient rooms present the highest part of external surface, along with connective spaces [6]. This factor is one of the elements contributing to the significant energy use of IPUs and its negative impact is proportional to the level of obsolescence of the building envelope. To understand the influence of building obsolescence, it is important to highlight that in Italy, as in most other European countries, about $60 \%$ of the healthcare facilities were built before $1980[7,8]$.

Being one of the most vulnerable elements of the building envelope, windows have usually represented a critical aspect in architectural design as, if not properly conceived, they can sometimes have a negative impact on the building energy needs. For this reason, large openings have been often avoided. However, with a proper building design, the adoption of wider fenestration systems can translate into significant energy savings and occupant comfort improvement, thus reducing operating and investment costs and increasing hospital resilience. When provided with low-emission coatings, larger windows allow one to cut heat losses during the heating period, and the application of solar selective films enables one to lower the cooling load due to solar radiation. Furthermore, with a greater availability of natural light, artificial lighting energy consumption may be reduced up to $25 \%$, with a decrease in maintenance costs associated with lamp replacement [9].

On the other hand, a well-designed daylighting is extremely useful not only from an energy performance perspective. A large number of studies have shown that natural brightness and outside views are important to improve the health of patients and hospital staff, highly increasing their psychophysical well-being [10-17]. Patients exposed to significant daylight are characterized by less suffering, thus requiring less drugs for pain relief [18]. Indeed, natural light promotes serotonin production and vitamin D synthesis. The former contributes to alleviate pain feeling, while the latter, if lacking, may cause musculoskeletal suffering $[19,20]$. Similar findings were demonstrated by Ulrich in 1984, who noticed that patients with views to nature were characterized by a lower Average Length of Stay (ALOS) if compared with those ones with just a view of neighboring buildings [21]. The benefit of an exposure to daylight has been studied also for people with depression [22-27] and related with a lower death rate in patients affected by cardiovascular diseases or cancer [28,29]. As regards hospital staff, they shown an improved alertness, less stress and were found to be more satisfied with their job [30,31].

Moreover, the increased daylight availability in hospital patient rooms, by lowering energy use, improving efficacy of healthcare delivery and shortening patient ALOS [21,32-34], allows one to significantly cut healthcare expenditures [9,18] (equal to about $€ 162$ per patient in Italy) [35], with highly positive impacts on the economic sustainability of hospitals.

In 2016 the global health expenditure accounted for roughly 10\% of the Gross Domestic Product (GDP), with the United States spending the most of any nation by far on its healthcare system $(17.1 \%)$ [36]. Considering Italy, the country national health service expenditures have increased of about $30 \%$ in the last twenty years, reaching $8.9 \%$ of GDP [36] and requiring resources that could have been used for other healthcare purposes. Therefore, hospital budgets getting tighter and political pressure reducing healthcare expenditures underline the need of forecasting and assessing this energy and cost saving potential.

The majority of studies on this topic focuses on the positive effects of windows on building occupants' well-being, but rarely investigates the role of glazing types, size and orientation as well as their effects on building energy use.

A large amount of literature examined the beneficial effects of daylight on people working in offices [37-39], some of these also took into account the impact of diverse window sizes, quantity, and distribution [40]. Indeed, research results demonstrated that windows characterized by $20 \%-25 \%$ Window-to-Wall Ratio (WWR) were considered too small, while openings with WWR higher than $30 \%-35 \%$ were perceived to be too large [41,42]. Several works analyzed how exposure to natural light may positively impact on children health and improve their learning progress $[43,44]$.

Despite this huge set of topics deeply investigated by literature, only very few studies focused on the relation between window size and patient satisfaction, that seems to be achieved when window area 
occupies $20 \%-30 \%$ of the external wall [45], while only some recent approaches took into consideration window orientation, from which it strictly depends the amount of solar radiation entering the space, thereby the amount of solar heat gain, thermal losses and daylight. Choi et al. observed that patients hospitalized in rooms facing south-east had $16 \%-41 \%$ shorter ALOS compared to patients in north-west oriented rooms [33]. Likewise, Benedetti et al. found that exposure to east daylight may reduce ALOS by about 3.67 days compared to access to natural light coming from the west [34].

Some works examined windows with diverse dimensions, orientation and glazing properties [46,47] in residential buildings [48-51], in a lecture room [52] and in office buildings [53-58], while Sarbu and Sebarchievici [59] reported the relation between the window height, U-value, outdoor air temperature and air velocity were able to ensure local thermal comfort.

Several software tools are available for assessing the influence of windows on building energy consumption, like EFEN, using EnergyPlus simulation engine [60], COMFEN, developed by Lawrence Berkeley National Laboratory [61] and MIT Design Advisor by the Massachusetts Institute of Technology (MIT) School of Architecture and Planning [62].

However, only a limited number of works conducted a comprehensive analysis of the impact of window size, orientation and kinds of glazing on patient rooms energy use, hampering the development of a reliable and exhaustive benchmark dataset. Cesari et al. [63] focused on the impact of these variables on heating and cooling energy needs by adopting wider openings, without analyzing the energy savings achievable on lighting energy demand. Furthermore, the study [63] did not evaluate glazing energy performance under different climatic conditions.

The present work aimed at assessing and comparing the influence of windows with diverse dimensions and glazing properties on the energy demand of a hospital patient room under different orientations and four climatic conditions. The objective was to evaluate the energy savings that can be obtained when larger windows are preferred and to identify the glazing specifications allowing one to reach the maximum energy reductions.

The analysis was conducted on the basis of the energy model of the whole hospital facility and focused on the patient room energy demand with the purpose of achieving the most robust results. The final purpose was to build a reliable reference dataset that may also assist architects and engineers in identifying the most effective glazing solutions when renovating a hospital building, as well as to pave the base to new hospital standards.

\section{Structure of the Method of Analysis}

As reported by the studies reviewed above, with proper building design, the adoption of windows with appropriate glazing specifications may drastically reduce the energy needs and costs related to the patient room, and, particularly, its building envelope, while increasing patient comfort.

Albeit window properties like the U-value and g-value are provided by manufacturers, energy saving interventions involving the building envelope require to consider the interaction and variation of different features, like occupancy schedules, morphological aspects of the building, operating hours, both indoor design and outdoor thermo-hygrometric conditions, control systems, etc.

Dynamic building energy simulation software is used to analyze the savings achievable on building energy use while taking into account different variables [64-67], as well as their environmental impact [68-72].

In the present study, the dynamic building energy simulation program TRNSYS was used to calculate and compare the sensible energy needs for heating and cooling and the artificial lighting energy demand of a hospital patient room in relation to the following variables:

- $\quad$ Glazing types;

- Window sizes;

- Room orientations;

- Climatic conditions; 
- $\quad$ Lighting control strategies.

Considering the beneficial effects of wider windows and daylight reported by the literature reviewed above, this work investigates the effects of larger openings on patient room energy needs.

The analysis focused only on the sensible energy demand since window area, orientation and kind of glazing do not impact on latent loads [73].

The building volume was modelled with TRNSYS3D plugin for Google Sketchup, while all the non-geometry information like layer material properties, ventilation and infiltration profiles, heat gains, etc. were added in TRNBuild. The characteristics defined were saved in text files, which were then read by Type 56 during simulations carried out in Simulation Studio [74,75].

The multizone building model Type 56 calculates the energy balance as the convective and conductive heat flux to the air node defined by the following equation:

$$
\dot{Q}_{i}=\dot{Q}_{\text {surf }, i}+\dot{Q}_{i n f, i}+\dot{Q}_{v e n t, i}+\dot{Q}_{g, c, i}+\dot{Q}_{c p l g, i}
$$

where $\dot{Q}_{i}$ is the conductive and convective heat flux, $\dot{Q}_{s u r f, i}$ are the convective gains from surfaces, $\dot{Q}_{i n f, i}$ are the infiltration gains (air flow from outside only), $\dot{Q}_{v e n t, i}$ are the ventilations gains, $\dot{Q}_{g, c, i}$ are the internal convective gains (by people, equipment, illumination, radiators, etc.) and $\dot{Q}_{c p l g, i}$ are the gains related to convective air flow coming from adjacent thermal zones, while radiative heat flows to the walls and windows are defined as:

$$
\dot{Q}_{r, w_{i}}=\dot{Q}_{g, r, i, w_{i}}+\dot{Q}_{s o l, w_{i}}+\dot{Q}_{l o n g, w_{i}}+\dot{Q}_{\text {wall-gain }}
$$

where $\dot{Q}_{r, w_{i}}$ are the radiative gains for the wall surface temperature node, $\dot{Q}_{g, r, i, w_{i}}$ are the radiative air node internal gains received by walls, $\dot{Q}_{s o l, w_{i}}$ represents the solar gains through windows received by walls, $\dot{Q}_{l o n g, w_{i}}$ is the long wave radiation exchange between a wall and all the other walls and windows and $\dot{Q}_{\text {wall-gain }}$ is the user-specified heat flow to the wall or window surface. The unit of measure of the terms in Equations (1) and (2) is $\mathrm{kJh}^{-1}$.

Weather data of the four cities considered in the analysis were provided by Meteonorm database and weather stations, and are reported in the external text files read by Type 15 in Simulation Studio to evaluate gains from solar radiation [74].

\section{Case Study}

A typical hospital building representative of the Italian healthcare building stock was taken as a case study. Its characteristics were determined on the basis of the investigation reported in reference [6]. The hospital was supposed to be located in four Italian cities, Milan, Bologna, Rome and Naples, in order to analyze the room energy needs under different climate conditions.

Milan and Bologna have a humid subtropical climate (Cfa) [76], which is the most prevalent climate in Italy along with the hot-summer Mediterranean type (Csa), also typical of a wide area of the South-Eastern United States, South-Eastern South America, Eastern Asia and Eastern Australia. The cities of Rome and Naples were selected to represent the hot-summer Mediterranean type (Csa). Geographical and climatic characteristics of the cities analyzed are reported in Table 1.

\begin{tabular}{|c|c|c|c|c|c|c|c|}
\hline City & $\begin{array}{l}\text { Altitude } \\
(\mathrm{m})\end{array}$ & $\begin{array}{c}\text { HDD }\left({ }^{\circ} \mathrm{C} \text { Day }\right) \\
\text { Baseline: } 20^{\circ} \mathrm{C} \\
{[77]}\end{array}$ & $\begin{array}{c}\text { CDD }\left({ }^{\circ} \mathrm{C} \text { Day) }\right. \\
\text { Baseline: } 26^{\circ} \mathrm{C} \\
{[77]}\end{array}$ & $\begin{array}{c}\text { Annual GSR }{ }^{1} \\
\text { on the HP }{ }^{2} \\
\left(\mathrm{kWhm}^{-2}\right) \text { [78] }\end{array}$ & $\begin{array}{c}\text { Climatic Vector } \\
\text { Vc }[79,80]\end{array}$ & $\begin{array}{l}\text { Köppen Climate } \\
\text { Classification [76] }\end{array}$ & Heating Period \\
\hline Milan & 122 & 2404 & 31 & 1345 & 0.312 & $\mathrm{Cfa}$ & 15 October-15 April \\
\hline Rome & 20 & 1415 & 38 & 1562 & 0.408 & Csa & 1 November-15 April \\
\hline Naples & 17 & 1034 & 74 & 1589 & 0.516 & Csa & 15 November-31 March \\
\hline
\end{tabular}

Table 1. Climatic characteristics of the cities analyzed.

${ }^{1}$ Global solar radiation. ${ }^{2}$ Horizontal plane. 
The case study consisted of two linear volumes composed of seven floors and arranged perpendicular to each other in the shape of an L (Figure 1a). The facility has a covered area of $1196 \mathrm{~m}^{2}$ and a total conditioned floor area of $6680 \mathrm{~m}^{2}$, with a surface to volume ratio (S/V) equal to 0.41 .

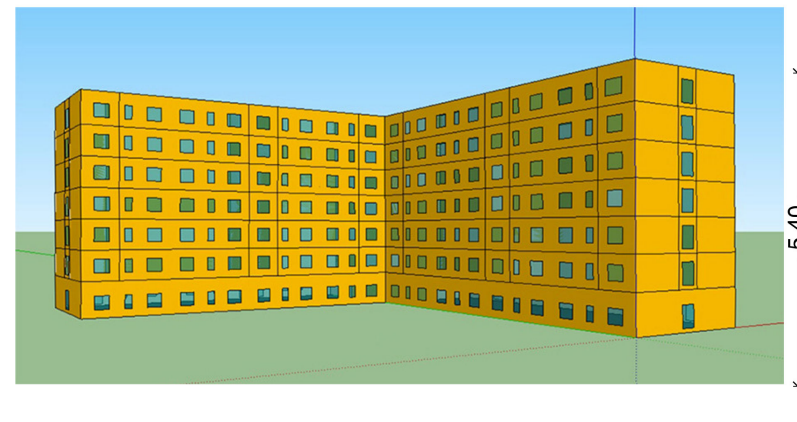

(a)

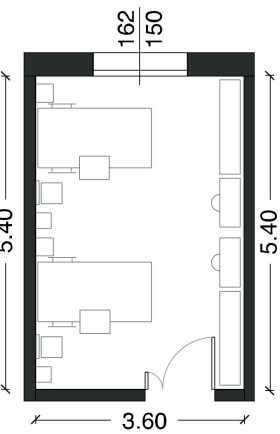

(b)

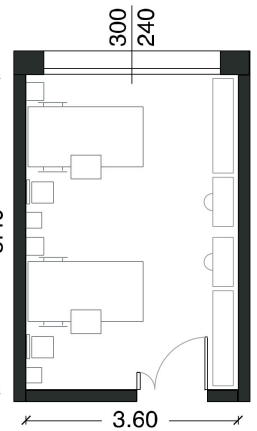

(c)

Figure 1. Perspective view of the hospital case study (a) and floor plans of the patient room with the two window sizes analyzed: $25 \%$ WWR window (b) and 77\% WWR window (c).

Simulations were conducted to assess the energy demand for space heating, cooling and lighting of a patient room situated on the third floor and facing no external obstruction. Volume and external area of the tested two-bed room were supposed to be $52.5 \mathrm{~m}^{3}$ and $7.3 \mathrm{~m}^{2}$ respectively. Being representative of the state of the Italian healthcare building stock, a building envelope with a very poor energy performance was assumed, with a thermal transmittance of the external wall of $1.40 \mathrm{Wm}^{-2} \mathrm{~K}^{-1}$. The floor plan and dimensions of the tested room are shown in Figure 1b,c.

The tested room, as well as the whole facility, is provided with an air conditioning system with 24/7 operation schedule [9,81]. A ventilation load of $1056 \mathrm{MWh}$ was considered. Indoor design thermohygrometric conditions, air infiltration rate and internal loads are reported in Table 2. The longwave emission coefficient of walls, ceiling and floor were assumed to be 0.9 .

Table 2. Temperature and relative humidity set-points, air infiltration rate and internal loads of the room.

\begin{tabular}{|c|c|c|c|c|c|}
\hline \multicolumn{2}{|c|}{ Temperature Set-Point $\left({ }^{\circ} \mathrm{C}\right)$} & \multirow{2}{*}{$\begin{array}{c}\text { Relative } \\
\text { Humidity (\%) }\end{array}$} & \multirow{2}{*}{$\begin{array}{l}\text { Air Infiltration } \\
\text { Rate }\left(\text { volh }^{-1}\right)\end{array}$} & \multicolumn{2}{|c|}{ Internal Loads Sensible Heat [82] } \\
\hline Winter & Summer & & & Patients (W) & Lamps $\left(\mathrm{Wm}^{-2}\right)$ \\
\hline 22 & 26 & 50 & 2.0 & 120 & 7.4 \\
\hline
\end{tabular}

The room was equipped with two recessed fluorescent lamps, $54 \mathrm{~W}$ each, for general lighting. In addition, two bed head units were installed, providing each bed with one $36 \mathrm{~W}$ fluorescent lamp for general lighting and two $18 \mathrm{~W}$ fluorescent lamps for reading and simple examination. The system was able to ensure a higher illuminance level than the minimum required by the standards, i.e., 100 lux for general lighting and 300 lux for reading and simple examination, measured at $0.03 \mathrm{~m}$ and $0.90 \mathrm{~m}$ above the floor respectively, as defined by UNI EN 12464-1:2011 regulation [83]. Considering that the two $54 \mathrm{~W}$ recessed fluorescent lamps are more than sufficient to meet the regulatory requirements for general lighting [83], and that the two $36 \mathrm{~W}$ lamps for general lighting and two of the fours $18 \mathrm{~W}$ lamps for reading and simple examination installed in the bed head units were turned on for a short period of time for medical needs, these lamps in the bed head units were not included in the evaluation. As the aim of the work was to analyze different types of glazing, the study does not consider the contribution of these lamps because their use does not depend on the glazing type, but it is due to the need of the medical staff to have additional lighting. The other two $18 \mathrm{~W}$ fluorescent lamps installed in the two bed head units for reading were assumed to be turned on for a limited period of time during the day $(4 \mathrm{~h})$. The related heat gains were assumed to be equal to the installed power for lighting, that is $7.4 \mathrm{Wm}^{-2}$ 
(Table 2), distributed between radiative and convective fraction according to the following shares: for recessed fluorescent lamps, $70 \%$ radiative fraction and 30\% convective fraction; for fluorescent lamps included in bed head units, 50\% radiative fraction and 50\% convective fraction, as reported by ASHRAE [84].

Artificial lighting was supposed to be on from $07.00 \mathrm{am}$ to $09.00 \mathrm{pm}$. In order to take full advantage of the beneficial effects of wider windows and, more in detail, of their contribution in maximizing energy savings, two lighting control systems were analyzed: an automatic on/off switch and a daylight-linked dimming control (Figure 2a,b). Indeed, studies available in literature have demonstrated that dimmable lighting control strategy dependent on daylight illuminance reduce lighting and cooling energy demand, allowing to achieve energy savings up to 40\% [85-90].

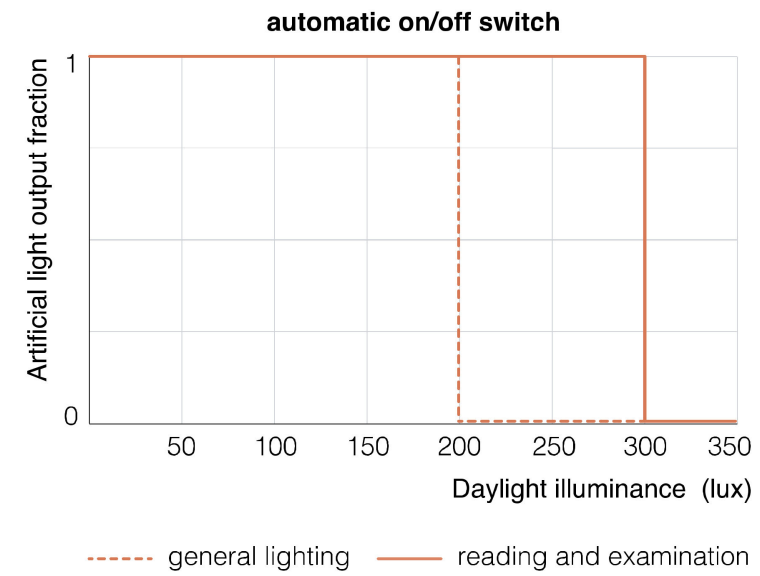

(a)

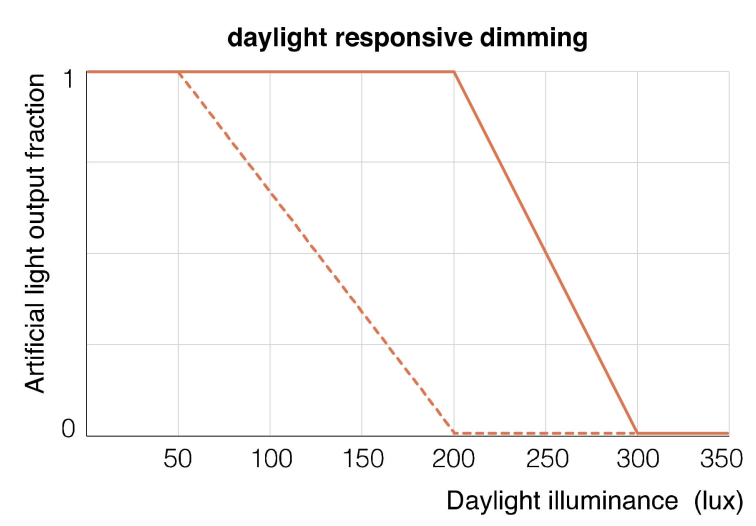

(b)

Figure 2. Definition of the two lighting control strategies analyzed according to the illuminance level required for general lighting and reading and examination.

The analysis considered two window dimensions: a common size opening, having an area of $2.43 \mathrm{~m}^{2}$ (1.62 m wide per $1.5 \mathrm{~m}$ height), equal to $25 \%$ WWR (Figure $1 \mathrm{~b}$ ); a floor to ceiling window, with an area of $7.2 \mathrm{~m}^{2}$ ( $3.0 \mathrm{~m}$ wide per $2.4 \mathrm{~m}$ height), equal to $77 \%$ WWR (Figure $1 \mathrm{c}$ ).

The wider window was supposed to be provided with a dynamic external shading device. Indeed, a growing body of literature $[56,57,91]$ has demonstrated that dynamic shading systems allow one to achieve the best energy savings and visual comfort compared to fixed solar shadings and the advantages of external screens (commonly used) have been widely investigated [57,92].

The control of the shading devices was defined in order to activate the system only during the cooling period and leave exposed $1.2 \mathrm{~m}^{2}$ of the window area to the sun when solar radiation incident on the window exceeded about $150 \mathrm{Wm}^{-2}\left(100 \mathrm{Wm}^{-2}\right.$ for a south-orientated façade and $200 \mathrm{Wm}^{-2}$ for a west or east-exposed façade), $0.6 \mathrm{~m}^{2}$ when solar radiation exceeded $400 \mathrm{Wm}^{-2}$ (for a north-exposed façade) [57] and $0.3 \mathrm{~m}^{2}$ from 14.00 to $16.00 \mathrm{pm}$, when drowsiness level of patients as well as ordinary people is higher during the day [93-99].

In view of the goal of this study, nine glazing systems with different U-values, g-values and visible transmittance (Tvis) were selected (data are reported in Table 3). All the glazing solutions were assumed to be provided with a frame having a thermal transmittance of $2.3 \mathrm{Wm}^{-2} \mathrm{~K}^{-1}$. 
Table 3. Glazing types specifications.

\begin{tabular}{cccc}
\hline $\begin{array}{c}\text { g-Value } \\
\text { (Dimensionless) }\end{array}$ & $\begin{array}{c}\text { U-Value } \\
\left.\mathbf{( W m}^{-2} \mathbf{K}^{-\mathbf{1}}\right)\end{array}$ & $\begin{array}{c}\text { Tvis } \\
\text { (Dimensionless) }\end{array}$ & Composition \\
\hline 0.79 & 2.89 & 0.75 & $4 / 12 / 4$ \\
0.57 & 1.40 & 0.77 & $44.2 / 14 / 44.4$ \\
& 1.10 & 0.77 & $44.2 / 16 / 44.4$ \\
0.46 & 1.40 & 0.69 & $44.2 / 14 / 44.4$ \\
& 1.10 & 0.69 & $44.2 / 14 / 44.4$ \\
& 0.70 & 0.69 & $44.2 / 16 / 4 / 16 / 44.4$ \\
0.40 & 1.40 & 0.66 & $44.2 / 14 / 44.4$ \\
& 1.10 & 0.66 & $44.2 / 14 / 44.4$ \\
& 0.70 & 0.66 & $44.2 / 16 / 4 / 16 / 44.4$ \\
\hline
\end{tabular}

In order to conduct a robust and reliable analysis, developed on the basis of the most realistic conditions, the selection of the glazing systems analyzed was made with the support of the technical department of two leading flat glass manufacturers.

The following criteria were considered:

- Compliance with regulatory thermal [100], safety [101] and acoustic [102] requirements;

- Commercial availability (the case study with a g-value of 0.57 and $\mathrm{U}$-value of $0.70 \mathrm{Wm}^{-2} \mathrm{~K}^{-1}$ was not investigated as it is not available on the market);

- Capacity to ensure the g-values, U-values and Tvis values selected by avoiding complex solutions and unnecessary costs when a more reasonable solution was available.

The Italian standard Decree 26/06/2015 [100] appoints specific limit values of window thermal transmittance in case of building energy refurbishment for the different Italian climate zones, as reported in Table 4. The regulatory threshold limit refers to the thermal transmittance of the whole fenestration system, composed by the glazing, the frame and the shutter box, and it is named as Uw-value. Regulation requires to comply with the defined standards from 1 January 2021.

Table 4. Regulatory limit values of thermal transmittance of the fenestration system in building energy refurbishment.

\begin{tabular}{cc}
\hline $\begin{array}{c}\text { Climate } \\
\text { Zone }\end{array}$ & $\begin{array}{c}\mathbf{U}_{\mathbf{W}} \text {-Value } \\
\left(\mathbf{W m}^{-\mathbf{2}} \mathbf{K}^{-\mathbf{1}}\right)\end{array}$ \\
\hline A and B & 3.0 \\
C & 2.0 \\
D & 1.8 \\
E & 1.4 \\
F & 1.0 \\
\hline
\end{tabular}

Although regulation allows one to use an Uw-value higher than $1.4 \mathrm{Wm}^{-2} \mathrm{~K}^{-1}$ for climate zones A, B, C and D, the size of window profiles currently commercially available brings to use a Uw-value of about $1.4 \mathrm{Wm}^{-2} \mathrm{~K}^{-1}$ also for these climate zones. An $\mathrm{Uw}$-value higher than $1.4 \mathrm{Wm}^{-2} \mathrm{~K}^{-1}$ requires smaller window profiles, which are no longer available.

The Italian standard UNI 7697:2015 [101], which regulates the installation of safety glazing in healthcare environments, requires a toughened or laminated glass outside and a laminated glass inside, according to a specific level of impact resistance [103], as reported in Table 5. 
Table 5. Classes of impact resistance required by regulation for safety glass application in hospitals.

\begin{tabular}{cccc}
\hline Risk & \multicolumn{2}{c}{ External Glass Sheet } & Internal Glass Sheet \\
\hline & Toughened & Laminated & Laminated \\
\hline damage to people & $1 \mathrm{C} 3^{1}$ & $2 \mathrm{~B} 2^{2}$ & $2 \mathrm{~B} 2$ \\
falling into the void & $1 \mathrm{C} 3$ & $2 \mathrm{~B} 2$ & $1 \mathrm{~B} 1^{3}$ \\
& & $1 \mathrm{~B} 1$ & $2 \mathrm{~B} 2$
\end{tabular}

${ }^{1}$ Resists an impact from a fall height of $190 \mathrm{~mm}$ without breaking. ${ }^{2}$ Resists an impact from a fall height 0 $450 \mathrm{~mm}$ without allowing penetration. ${ }^{3}$ Resists an impact from a fall height of $1200 \mathrm{~mm}$ without allowing penetration.

The necessity to use toughened or laminated glass requires panes with significant thickness, which limits g-value to maximum 0.60 .

The selected glazing systems were generated by means of WINDOW 7.5 [104], a software developed by the Lawrence Berkeley National Laboratory for calculating total window thermal performance indices. For each system, the specific glass types and gaps composing it (with the related specification, like the product name, manufacturer, color, thickness, visible and solar transmittance, visible and solar reflectance, conductivity, etc.) were selected from the international library included in the software. The program then calculated the performance data using updated algorithms consistent with ASHRAE SPC142 [105], ISO 15,099 [106] and generated a report (text file) containing all the window specifications (U-value, g-value, visible transmittance, relative heat gain, shading coefficient, etc.), in a format that may be added to the TRNBuild glazing library and then used by TRNSYS to calculate heating, cooling and lighting energy needs.

The glazings were analyzed for each window size, room orientation, lighting control strategy and city taken into consideration (Table 6), for a total number of 528 scenarios.

Table 6. Summary of the scenarios analyzed for each of the four cities considered, Milan, Bologna, Rome and Naples.

\begin{tabular}{|c|c|c|c|c|c|}
\hline n. & $\begin{array}{c}\mathrm{g} \text {-Value } \\
\text { (Dimensionless) }\end{array}$ & $\begin{array}{c}\text { U-Value } \\
\left(\mathrm{Wm}^{-2} \mathrm{~K}^{-1}\right)\end{array}$ & WWR (\%) & Orientation & Lighting Control Strategy \\
\hline 1 & 0.79 & 2.89 & 25 & $\mathrm{~W}$ & automatic on/off \\
\hline 2 & & & & $\mathrm{E}$ & automatic on/off \\
\hline 3 & & & & $S$ & automatic on/off \\
\hline 4 & & & & $\mathrm{~N}$ & automatic on/off \\
\hline 5 & 0.57 & 1.40 & 25 & W & automatic on/off \\
\hline 6 & & & & & dimming \\
\hline 7 & & & & E & automatic on/off \\
\hline 8 & & & & & dimming \\
\hline 9 & & & & S & automatic on/off \\
\hline 10 & & & & & dimming \\
\hline 11 & & & & $\mathrm{~N}$ & automatic on/off \\
\hline 12 & & & & & dimming \\
\hline 13 & & & 77 & W & automatic on/off \\
\hline 14 & & & & & dimming \\
\hline 15 & & & & E & automatic on/off \\
\hline 16 & & & & & dimming \\
\hline 17 & & & & $S$ & automatic on/off \\
\hline 18 & & & & & dimming \\
\hline 19 & & & & $\mathrm{~N}$ & automatic on/off \\
\hline 20 & & & & & dimming \\
\hline 21 & 0.57 & 1.10 & 25 & W & automatic on/off \\
\hline 22 & & & & & dimming \\
\hline 23 & & & & E & automatic on/off \\
\hline 24 & & & & & dimming \\
\hline 25 & & & & S & automatic on/off \\
\hline
\end{tabular}


Table 6. Cont.

\begin{tabular}{|c|c|c|c|c|c|}
\hline n. & $\begin{array}{c}\mathrm{g} \text {-Value } \\
\text { (Dimensionless) }\end{array}$ & $\begin{array}{c}\text { U-Value } \\
\left(\mathrm{Wm}^{-2} \mathrm{~K}^{-1}\right)\end{array}$ & WWR (\%) & Orientation & Lighting Control Strategy \\
\hline 26 & & & & & dimming \\
\hline 27 & & & & $\mathrm{~N}$ & automatic on/off \\
\hline 28 & & & & & dimming \\
\hline 29 & & & 77 & W & automatic on/off \\
\hline 30 & & & & & dimming \\
\hline 31 & & & & E & automatic on/off \\
\hline 32 & & & & & dimming \\
\hline 33 & & & & $\mathrm{~S}$ & automatic on/off \\
\hline 34 & & & & & dimming \\
\hline 35 & & & & $\mathrm{~N}$ & automatic on/off \\
\hline 36 & & & & & dimming \\
\hline 37 & 0.46 & 1.40 & 25 & $\mathrm{~W}$ & automatic on/off \\
\hline 38 & & & & & dimming \\
\hline 39 & & & & E & automatic on/off \\
\hline 40 & & & & & dimming \\
\hline 41 & & & & $\mathrm{~S}$ & automatic on/off \\
\hline 42 & & & & & dimming \\
\hline 43 & & & & $\mathrm{~N}$ & automatic on/off \\
\hline 44 & & & & & dimming \\
\hline 45 & & & 77 & W & automatic on/off \\
\hline 46 & & & & & dimming \\
\hline 47 & & & & E & automatic on/off \\
\hline 48 & & & & & dimming \\
\hline 49 & & & & $\mathrm{~S}$ & automatic on/off \\
\hline 50 & & & & & dimming \\
\hline 51 & & & & $\mathrm{~N}$ & automatic on/off \\
\hline 52 & & & & & dimming \\
\hline 53 & 0.46 & 1.10 & 25 & W & automatic on/off \\
\hline 54 & & & & & dimming \\
\hline 55 & & & & E & automatic on/off \\
\hline 56 & & & & & dimming \\
\hline 57 & & & & $\mathrm{~S}$ & automatic on/off \\
\hline 58 & & & & & dimming \\
\hline 59 & & & & $\mathrm{~N}$ & automatic on/off \\
\hline 60 & & & & & dimming \\
\hline 61 & & & 77 & W & automatic on/off \\
\hline 62 & & & & & dimming \\
\hline 63 & & & & E & automatic on/off \\
\hline 64 & & & & & dimming \\
\hline 65 & & & & $\mathrm{~S}$ & automatic on/off \\
\hline 66 & & & & & dimming \\
\hline 67 & & & & $\mathrm{~N}$ & automatic on/off \\
\hline 68 & & & & & dimming \\
\hline 69 & 0.46 & 0.70 & 25 & W & automatic on/off \\
\hline 70 & & & & & dimming \\
\hline 71 & & & & E & automatic on/off \\
\hline 72 & & & & & dimming \\
\hline 73 & & & & $\mathrm{~S}$ & automatic on/off \\
\hline 74 & & & & & dimming \\
\hline 75 & & & & $\mathrm{~N}$ & automatic on/off \\
\hline 76 & & & & & dimming \\
\hline 77 & & & 77 & W & automatic on/off \\
\hline 78 & & & & & dimming \\
\hline 79 & & & & E & automatic on/off \\
\hline 80 & & & & & dimming \\
\hline 81 & & & & $\mathrm{~S}$ & automatic on/off \\
\hline
\end{tabular}


Table 6. Cont.

\begin{tabular}{|c|c|c|c|c|c|}
\hline n. & $\begin{array}{c}\text { g-Value } \\
\text { (Dimensionless) }\end{array}$ & $\begin{array}{c}\text { U-Value } \\
\left(\mathrm{Wm}^{-2} \mathrm{~K}^{-1}\right)\end{array}$ & WWR (\%) & Orientation & Lighting Control Strategy \\
\hline 82 & & & & & dimming \\
\hline 83 & & & & $\mathrm{~N}$ & automatic on/off \\
\hline 84 & & & & & dimming \\
\hline 85 & 0.40 & 1.40 & 25 & W & automatic on/off \\
\hline 86 & & & & & dimming \\
\hline 87 & & & & E & automatic on/off \\
\hline 88 & & & & & dimming \\
\hline 89 & & & & $S$ & automatic on/off \\
\hline 90 & & & & & dimming \\
\hline 91 & & & & $\mathrm{~N}$ & automatic on/off \\
\hline 92 & & & & & dimming \\
\hline 93 & & & 77 & $\mathrm{~W}$ & automatic on/off \\
\hline 94 & & & & & dimming \\
\hline 95 & & & & E & automatic on/off \\
\hline 96 & & & & & dimming \\
\hline 97 & & & & S & automatic on/off \\
\hline 98 & & & & & dimming \\
\hline 99 & & & & $\mathrm{~N}$ & automatic on/off \\
\hline 100 & & & & & dimming \\
\hline 101 & 0.40 & 1.10 & 25 & W & automatic on/off \\
\hline 102 & & & & & dimming \\
\hline 103 & & & & E & automatic on/off \\
\hline 104 & & & & & dimming \\
\hline 105 & & & & $S$ & automatic on/off \\
\hline 106 & & & & & dimming \\
\hline 107 & & & & $\mathrm{~N}$ & automatic on/off \\
\hline 108 & & & & & dimming \\
\hline 109 & & & 77 & W & automatic on/off \\
\hline 110 & & & & & dimming \\
\hline 111 & & & & $\mathrm{E}$ & automatic on/off \\
\hline 112 & & & & & dimming \\
\hline 113 & & & & S & automatic on/off \\
\hline 114 & & & & & dimming \\
\hline 115 & & & & $\mathrm{~N}$ & automatic on/off \\
\hline 116 & & & & & dimming \\
\hline 117 & 0.40 & 0.70 & 25 & W & automatic on/off \\
\hline 118 & & & & & dimming \\
\hline 119 & & & & E & automatic on/off \\
\hline 120 & & & & & dimming \\
\hline 121 & & & & $S$ & automatic on/off \\
\hline 122 & & & & & dimming \\
\hline 123 & & & & $\mathrm{~N}$ & automatic on/off \\
\hline 124 & & & & & dimming \\
\hline 125 & & & 77 & W & automatic on/off \\
\hline 126 & & & & & dimming \\
\hline 127 & & & & $\mathrm{E}$ & automatic on/off \\
\hline 128 & & & & & dimming \\
\hline 129 & & & & $S$ & automatic on/off \\
\hline 130 & & & & & dimming \\
\hline 131 & & & & $\mathrm{~N}$ & automatic on/off \\
\hline 132 & & & & & dimming \\
\hline
\end{tabular}

\section{Results and Discussion}

The results obtained by simulations were outlined in the following lines, where energy needs for heating, cooling and lighting converted into primary energy demand (PED) were reported. For the 
conversion it was assumed a global efficiency of the heating system (powered by natural gas boiler) equal to 0.68 , assessed by considering all the efficiencies values of the system (emission and control, distribution and generation) [107]; the average efficiency of the electricity production system in Italy, equal to 0.46 [108-110]; a conversion factor of 0.92 for cooling energy demand, obtained from the product between the emission and control efficiency, the distribution efficiency of the system, an energy efficiency ratio EER for the electric chiller of 2.7 and the average efficiency of the national electricity production system.

A first analysis of the data expressed in absolute values (reported in Appendix A for the sake of brevity) underlines that heating primary energy needs were decisively the main contributors to the primary energy demand of the patient room, being responsible for about $82 \%$ ( $88 \%$ in Milan, $85 \%$ in Bologna, $80 \%$ in Rome and $77 \%$ in Naples), followed by lighting and cooling primary energy needs, equal to about $11 \%$ and $7 \%$ respectively.

The percentage changes in heating $\left(P E D_{H}\right)$, cooling $\left(P E D_{C}\right)$, lighting $\left(P E D_{L}\right)$ and total $\left(P E D_{T}\right)$ primary energy demand of the patient room analyzed for the city of Milan (Table 7), Bologna (Table 8), Rome (Table 9) and Naples (Table 10) are reported below.

Table 7. Percentage change in primary energy demand for heating, cooling and lighting evaluated for each glazing type and lighting control strategy compared to the base case in Milan.

\begin{tabular}{|c|c|c|c|c|c|c|c|}
\hline \multicolumn{8}{|c|}{ Milan } \\
\hline $\begin{array}{c}\text { g-Value } \\
\text { (Dimensionless) }\end{array}$ & $\begin{array}{c}\text { U-Value } \\
\left(\mathrm{Wm}^{-2} \mathrm{~K}^{-1}\right)\end{array}$ & WWR (\%) & Lighting Control Strategy & $\triangle P E D_{H}(\%)$ & $\triangle P E D_{C}(\%)$ & $\triangle P E D_{L}(\%)$ & $\triangle P E D_{T}(\%)$ \\
\hline \multirow[t]{3}{*}{0.57} & 1.40 & 77 & automatic on/off & -9 & -21 & -16 & -10 \\
\hline & & & dimming & -7 & -25 & -51 & -13 \\
\hline & 1.10 & 77 & automatic on/off & -11 & -19 & -16 & -12 \\
\hline \multirow{5}{*}{0.46} & & & dimming & -3 & -39 & -50 & -10 \\
\hline & 1.10 & 77 & automatic on/off & -8 & -34 & -15 & -10 \\
\hline & & & dimming & -6 & -38 & -50 & -13 \\
\hline & 0.70 & 77 & automatic on/off & -12 & -32 & -14 & -14 \\
\hline & & & dimming & -10 & -36 & -50 & -16 \\
\hline \multirow[t]{2}{*}{0.40} & 1.40 & 77 & automatic on/off & -2 & -41 & -14 & -6 \\
\hline & & & dimming & -9 & -42 & -50 & -15 \\
\hline
\end{tabular}

Table 8. Percentage change in primary energy demand for heating, cooling and lighting evaluated for each glazing type and lighting control strategy compared to the base case in Bologna.

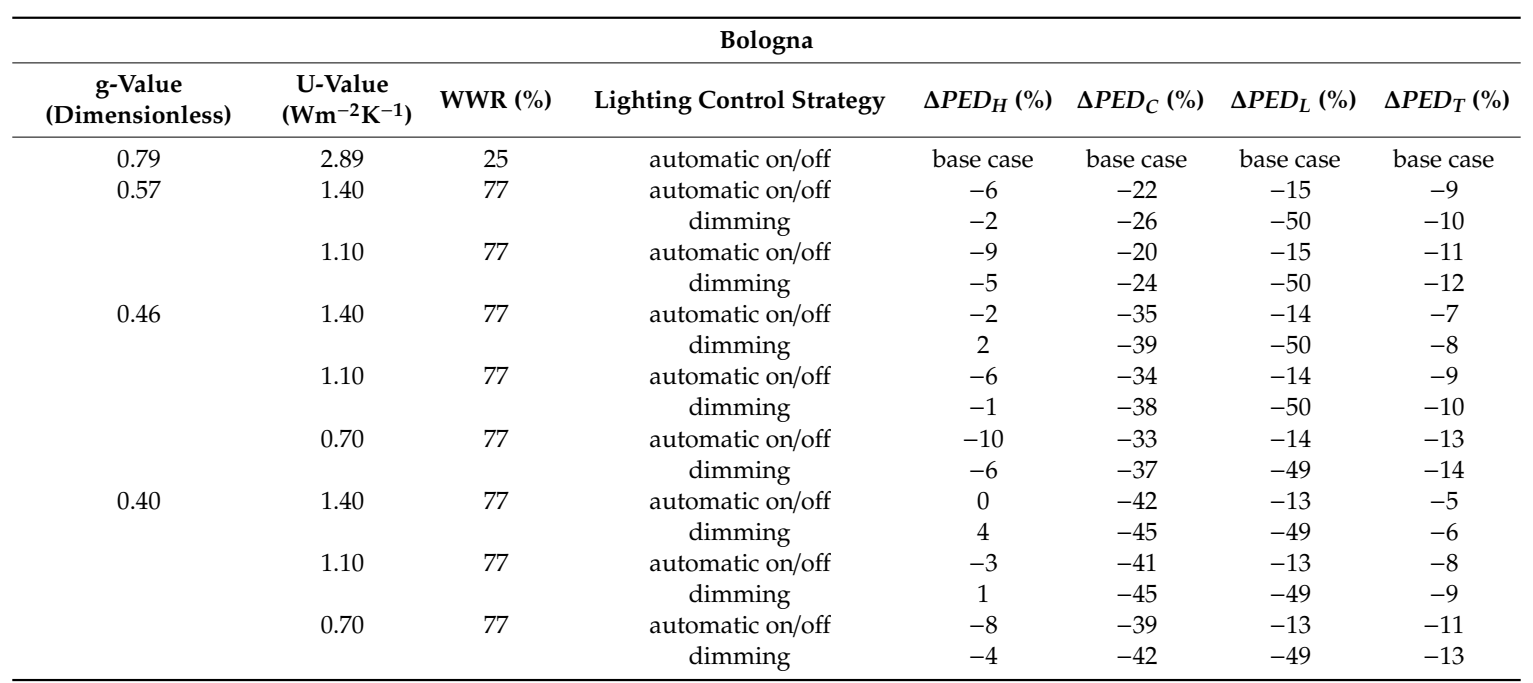


Table 9. Percentage change in primary energy demand for heating, cooling and lighting evaluated for each glazing type and lighting control strategy compared to the base case in Rome.

\begin{tabular}{|c|c|c|c|c|c|c|c|}
\hline \multicolumn{8}{|c|}{ Rome } \\
\hline $\begin{array}{c}\text { g-Value } \\
\text { (Dimensionless) }\end{array}$ & $\begin{array}{c}\text { U-Value } \\
\left(\mathrm{Wm}^{-2} \mathrm{~K}^{-1}\right)\end{array}$ & WWR (\%) & Lighting Control Strategy & $\triangle P E D_{H}(\%)$ & $\triangle P E D_{C}(\%)$ & $\triangle P E D_{L}(\%)$ & $\triangle P E D_{T}(\%)$ \\
\hline 0.79 & 2.89 & 25 & automatic on/off & base case & base case & base case & base case \\
\hline \multirow[t]{4}{*}{0.57} & 1.40 & 77 & automatic on/off & -11 & -22 & -12 & -12 \\
\hline & & & dimming & -6 & -27 & -48 & -15 \\
\hline & 1.10 & 77 & automatic on/off & -15 & -20 & -11 & -15 \\
\hline & & & dimming & -10 & -25 & -47 & -17 \\
\hline \multirow[t]{6}{*}{0.46} & 1.40 & 77 & automatic on/off & -3 & -36 & -10 & -7 \\
\hline & & & dimming & 3 & -41 & -47 & -10 \\
\hline & 1.10 & 77 & automatic on/off & -7 & -35 & -10 & -10 \\
\hline & & & dimming & -1 & -40 & -47 & -12 \\
\hline & 0.70 & 77 & automatic on/off & -12 & -33 & -10 & -14 \\
\hline & & & dimming & -7 & -38 & -47 & -16 \\
\hline \multirow[t]{6}{*}{0.40} & 1.40 & 77 & automatic on/off & 2 & -43 & -9 & -5 \\
\hline & & & dimming & 8 & -47 & -46 & -7 \\
\hline & 1.10 & 77 & automatic on/off & -2 & -42 & -9 & -7 \\
\hline & & & dimming & 3 & -46 & -46 & -10 \\
\hline & 0.70 & 77 & automatic on/off & -8 & -39 & -9 & -12 \\
\hline & & & dimming & -3 & -44 & -46 & -14 \\
\hline
\end{tabular}

Table 10. Percentage change in primary energy demand for heating, cooling and lighting evaluated for each glazing type and lighting control strategy compared to the base case in Naples.

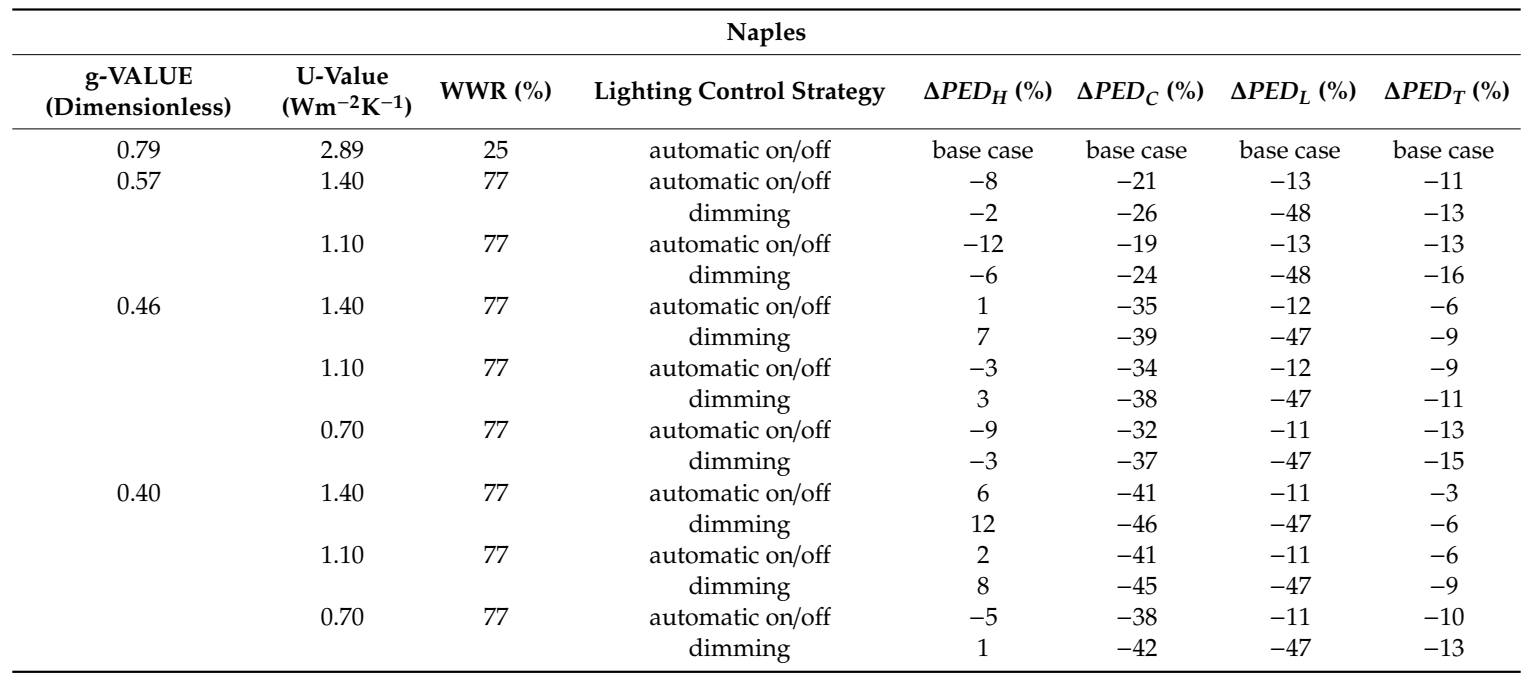

As energy needs were found to vary between the four different orientations with a very similar trend for all the glazing types examined, a further analysis focused only on the results obtained for the $77 \%$ WWR window facing west. Only findings regarding west-facing glazings were further examined as this orientation allows us to achieve the maximum savings both on heating and cooling energy needs. Moreover, taking into account the obsolescence level of the majority of the healthcare building stock, the scenario with a $25 \% W W R$ window characterized by a U-value of $2.89 \mathrm{Wm}^{-2} \mathrm{~K}^{-1}$ and a g-value of 0.79 was considered symbolic of the state of most existing hospitals in Italy. Therefore, this condition was assumed the reference condition against which to benchmark potential energy savings, and it was called the "base case" scenario.

The comparison of the achievable percentage savings shows that heating primary energy demand is characterized by the lowest decrease, with potential savings ranging from about $8 \%$ for Milan, $6 \%$ for Bologna, $7 \%$ for Rome and $4 \%$ for Naples (Tables 7-10 and Figure 3). 


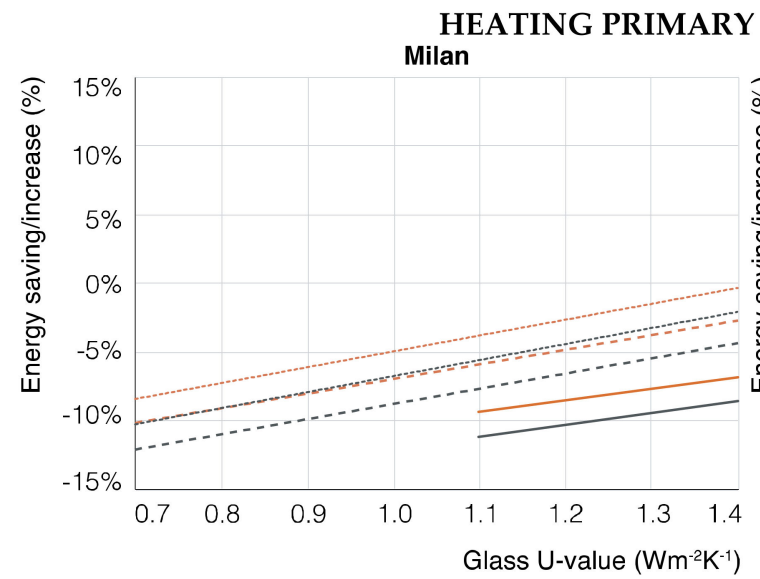

(a)

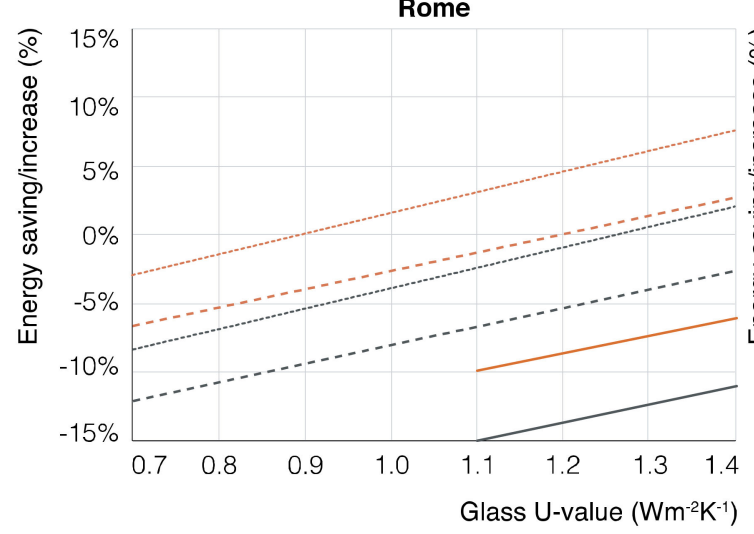

(c)

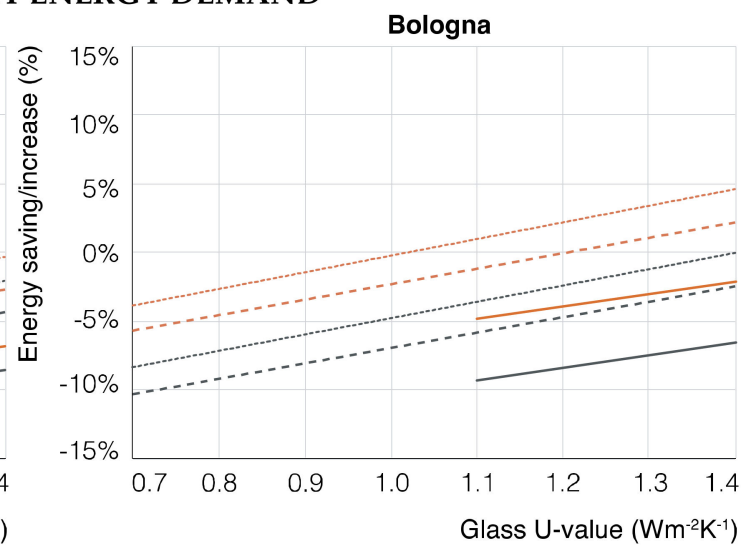

(b)

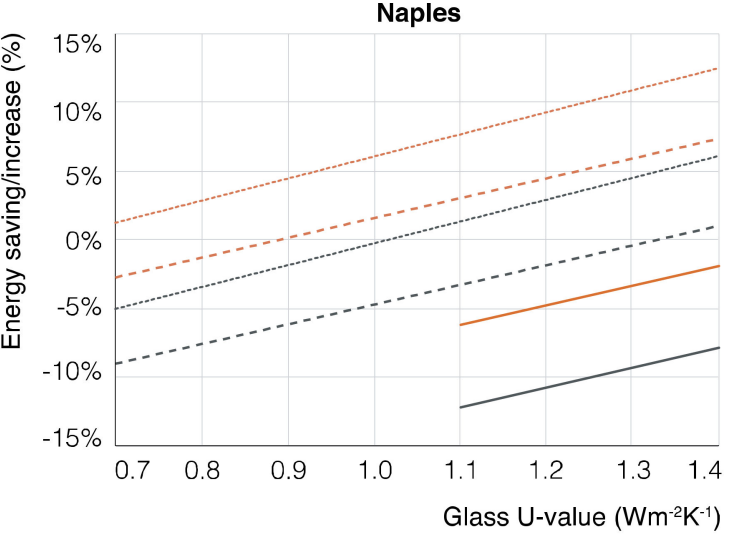

(d)

automatic on/off switch dimming

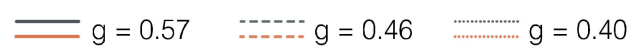

Figure 3. Percentage reduction or increase in heating primary energy demand compared to the west-facing base case by adopting the 77\% WWR window in relation to the U-value, g-value and lighting control strategy.

Maximum savings on lighting and cooling primary energy needs were obtained with a dimmable lighting control strategy dependent on daylight illuminance, rather than an automatic on/off switch. Indeed, the former allows one to save nearly $40 \%$ more energy than the latter. Furthermore, savings on lighting primary energy demand were generally more significant than those on cooling, as illustrated in Figures 4 and 5. Indeed, the former range from 47\%, for the cities of Rome and Naples, to 50\% for Milan and Bologna, while the latter were equal to about 37\% (Tables 7-10).

Nevertheless, for a proper understanding of the results obtained it is necessary to analyze the data in view of the breakdown of primary energy demand by end-use. As mentioned before, primary energy needs for heating represent about $82 \%$ of the total room primary energy demand, followed by lighting $(11 \%)$ and cooling $(7 \%)$. Therefore, when considering potential reductions in energy expressed in absolute values, heating energy savings are generally higher or almost equal to the savings achievable on cooling primary energy demand for the cities with higher heating degree days (HDD; Milan and Bologna). In regards to the lighting, it was found to be the end use on which the highest savings could be obtained also when analyzing the results expressed in absolute values (Appendix A).

Considering the balance between heating, cooling and lighting energy savings, the most advantageous glazing solutions are those characterized by a g-value of 0.40 and 0.46 and a U-value of $0.70 \mathrm{Wm}^{-2} \mathrm{~K}^{-1}$ for the cities of Milan and Bologna, and the glazing type with a g-value of 0.57 and a $\mathrm{U}$-value of $1.10 \mathrm{Wm}^{-2} \mathrm{~K}^{-1}$ for the cities of Rome and Naples, for which the second glazing solution is the best as well. 


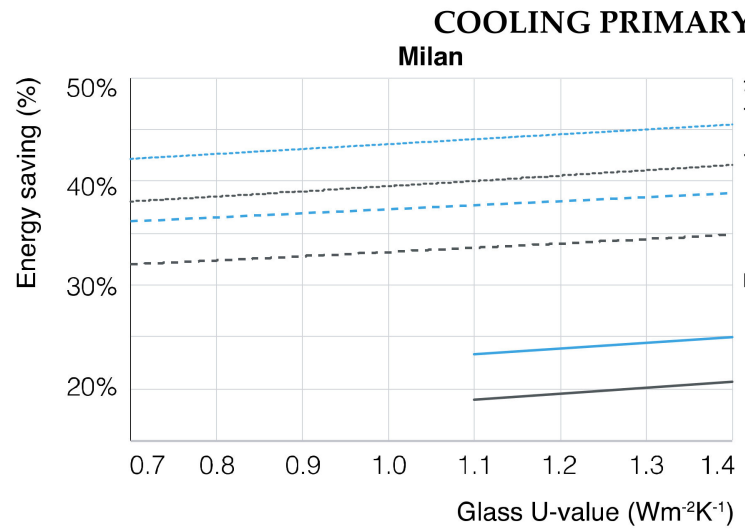

(a)

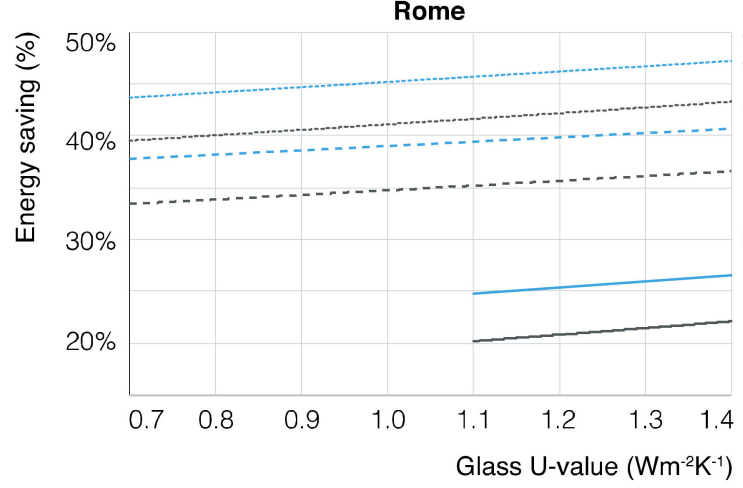

(c)

automatic on/off switch dimming

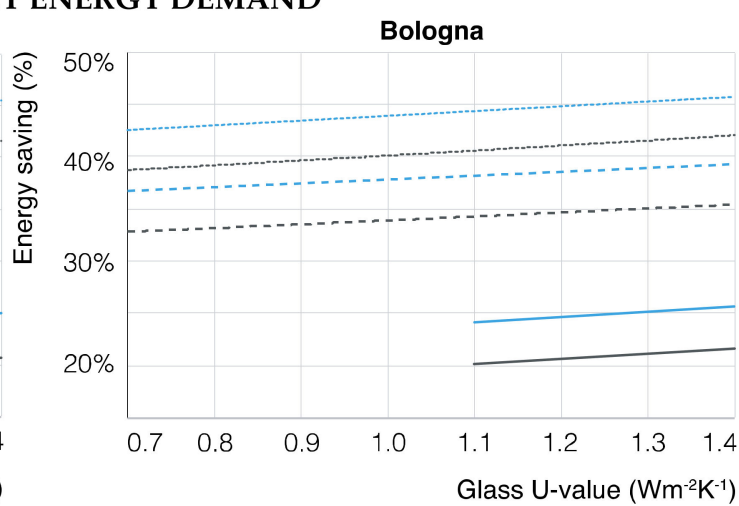

(b)

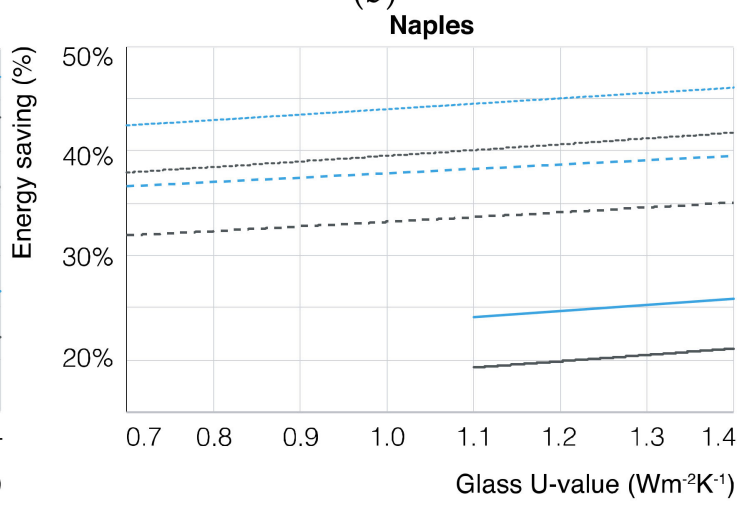

(d)

Figure 4. Achievable savings on cooling primary energy demand of the west-facing base case by adopting the 77\% WWR window in relation to its U-value, g-value and lighting control strategy.

The most significant savings on cooling primary energy needs may be achieved with the glazing type characterized by a g-value of 0.40 and a U-value of $1.40 \mathrm{Wm}^{-2} \mathrm{~K}^{-1}$, when a daylight-linked dimming control was adopted, as illustrated in Figure 4. This glazing solution allows us to reduce cooling primary energy demand by up to $47 \%$ for Rome (Table 9), $46 \%$ for Naples (Table 10) and $45 \%$ for the cities of Milan (Table 7) and Bologna (Table 8).

Nevertheless, this glazing type brings to the lowest savings or highest increase in heating primary energy needs too, equal to a $1 \%$ reduction for Milan (Table 7 ) and a rise of $4 \%$ for Bologna (Table 8 ), $8 \%$ for Rome (Table 9 ) and $12 \%$ for Naples (Table 10).

Indeed, appropriate values of glazing specifications to reduce primary energy needs for heating are opposite to those necessary to maximize savings on cooling primary energy demand (Figures 3 and 4).

Considering the lighting primary energy demand, Figure 5 outlines that all the glazing types considered allowed us to achieve nearly the same energy savings, being characterized by more or less the same value of visible transmittance (Tvis). The highest savings on primary energy needs for lighting may be obtained in Bologna and Milan, with a reduction of 50\% when adopting a daylight-linked dimming control. 


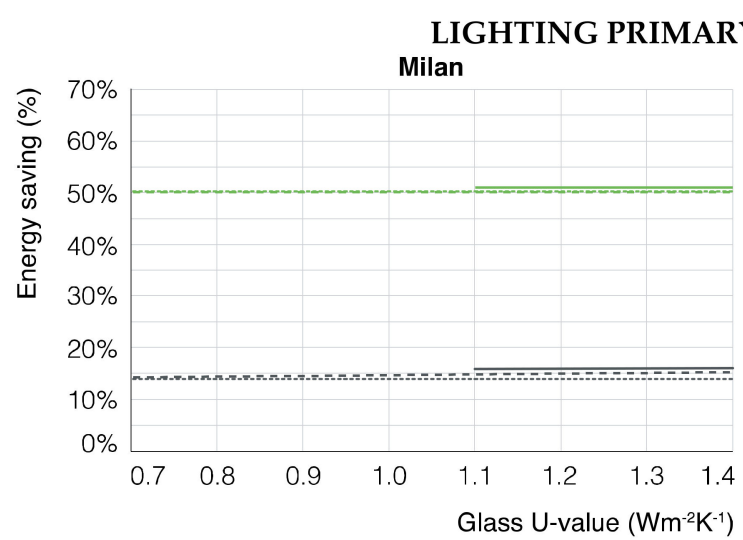

(a)

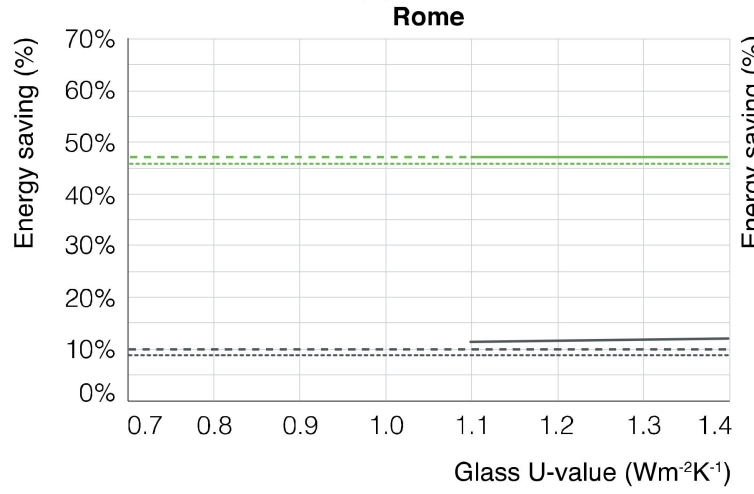

(c)

automatic on/off switch dimming

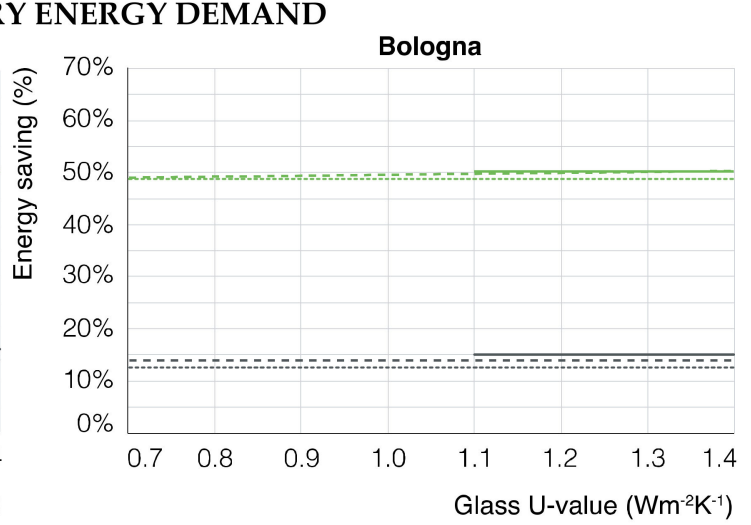

(b)

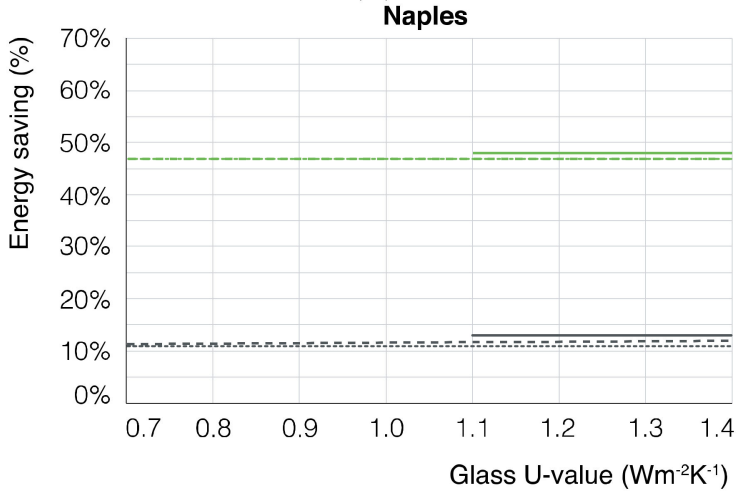

(d)

Figure 5. Achievable savings on lighting primary energy demand of the west-facing base case by adopting the $77 \%$ WWR window in relation to its U-value, g-value and lighting control strategy.

\section{Conclusions and Future Developments}

The adoption of wider openings with appropriate glazing specifications can dramatically lower energy needs and the related costs in hospital patient rooms, while improving patient and staff well-being, which benefits from the increased exposure to daylight and to an outside open sky view.

The present study assessed and compared the effects of several window dimensions and glazing properties on the primary energy demand for heating, cooling and lighting of a hospital patient room under four orientations and four climatic conditions using dynamic building energy simulations. More in detail, the performance of a base case window with $25 \%$ WWR, thermal transmittance of 2.89 $\mathrm{Wm}^{-2} \mathrm{~K}^{-1}$ and g-value of 0.79 was compared to a $77 \%$ WWR window under nine glazing systems with different U-values and g-values and considering four orientations and four climatic conditions-Milan, Bologna, Rome and Naples.

Furthermore, two lighting control systems were analyzed, an automatic on/off switch and a dimmable lighting control strategy dependent on natural light illuminance, in order to take full advantage of the positive effects of wider windows and, more in detail, of their contribution in maximizing energy savings.

Results reported above showed that appropriate glazing specifications to achieve the highest heating energy savings were opposite to those necessary to reduce the primary energy demand for cooling. The glazing solution with a g-value of 0.40 and a U-value of $1.40 \mathrm{Wm}^{-2} \mathrm{~K}^{-1}$ allowed us to obtain the best savings on cooling primary energy needs (up to $47 \%$ ), but it brought the highest increase in heating primary energy demand too. This is due to the fact that heating loads can be reduced by adopting glazings with low $\mathrm{U}$-values for low heat losses and high g-values to increase solar gains. However, these characteristics are not energy-efficient during the cooling period. This finding 
underlines the need to separately consider heating and cooling primary energy needs when selecting the best glazing solution. More in detail, for each location it is necessary to analyze the weather data in order to identify the end use that contributes the most to the overall primary energy demand.

Taking into consideration heating, cooling and lighting primary energy needs individually, the highest energy savings could be achieved on the lighting primary energy demand, which could be reduced up to $50 \%$ when a daylight responsive dimming control is adopted. Slightly lower savings, approximately equal to $37 \%$, could be reached on primary energy needs for cooling, while the lowest percentage reductions were achieved on the heating primary energy demand, varying from about $8 \%$ to $4 \%$. Although, being heating the most responsible end use for total primary energy needs, when considering results expressed in absolute values the savings achievable on heating were higher or nearly equal to those on cooling for the cities with higher heating degree days (HDD; Milan and Bologna). Despite this, lighting was found to be the end use on which the maximum savings could be reached also when considering results expressed in absolute values (Appendix A).

In regards to the balance between the energy savings achievable on heating, cooling and lighting primary energy needs, the most advantageous glazing solution was the one with a g-value of 0.40 and 0.46 and a U-value of $0.70 \mathrm{Wm}^{-2} \mathrm{~K}^{-1}$ for the cities with higher heating degree days (HDD) (Milan and Bologna), and with a g-value of 0.57 and a U-value of $1.10 \mathrm{Wm}^{-2} \mathrm{~K}^{-1}$ for the cities with lower heating degree days (Rome and Naples).

For a more comprehensive interpretation of the findings obtained it is necessary to underline that optimizing the type of glazing and lighting control strategy in hospital patient rooms did not only allow us to reduce energy consumption and cut energy-related costs. As outlined in Table 11, for each $\mathrm{kWh}$ of electricity or natural gas, 0.45 and $0.20 \mathrm{~kg}$ carbon dioxide emissions $\left(\mathrm{kgCO}_{2}\right)$ were released respectively.

Table 11. Carbon dioxide emission conversion factors [108,111-114].

\begin{tabular}{cc}
\hline Fuel & $\mathbf{k g C O}_{\mathbf{2}}$ per $\mathbf{k W h}$ \\
\hline Electricity & 0.45 \\
Gas & 0.20 \\
\hline
\end{tabular}

Therefore, taking into account the glazing solutions that allow us to achieve the maximum energy savings on all the end uses, it was found that those characterized by a g-value of 0.46 and a U-value of $0.70 \mathrm{Wm}^{-2} \mathrm{~K}^{-1}$, for the cities of Milan and Bologna, and the glazing types with a g-value of 0.57 and a $\mathrm{U}$-value of $1.10 \mathrm{Wm}^{-2} \mathrm{~K}^{-1}$, for the cities of Rome and Naples, enabled to cut the related carbon emissions in a range between 111 and $205 \mathrm{kgCO}_{2}$ per year, equal to $14 \%-17 \%$ (Table 12). Considered that health carbon footprint represents about $5 \%$ of the national carbon footprint in OECD countries- $10 \%$ in the U.S., $7 \%$ in Australia and 5\% in Italy [115] — the application of measures aimed at reducing carbon emissions results to be of the utmost urgency.

Table 12. Reduction in carbon emissions.

\begin{tabular}{cccc}
\hline City & \multirow{2}{*}{ Primary Energy Savings $\mathbf{( k W h )}$} & \multicolumn{2}{c}{ Reduction in Carbon Emissions } \\
\cline { 3 - 4 } & & $\mathbf{( \mathbf { k g C O } _ { \mathbf { 2 } } \mathbf { ) }}$ \\
\hline Milan & 1010 & 205 & $\mathbf{( \% )}$ \\
Bologna & 719 & 147 & 16 \\
Rome & 655 & 134 & 17 \\
Naples & 542 & 111 & 16 \\
\hline
\end{tabular}

Savings achievable on the primary energy demand for heating may be maximized by activating the shading systems during the night in order to further reduce thermal losses. This issue will be properly investigated in the next research steps. In addition, a cost-optimal analysis of the solutions 
analyzed will be conducted with the aim of developing a robust decision-making tool that could support professionals when designing measures for a building energy refurbishment. Among the future developments of the study will be the analysis of (i) the dynamic primary energy calculation considering in the simulation the time depending efficiency of the electric energy provided by the grid and (ii) the carbon dioxide emissions taking into account its time depending factor.

Author Contributions: S.C. contributed to the definition of the model, the simulations' conditions and carried out the simulations. P.V. and M.C. designed and implemented the simulation tools, S.M. gave the direct supervision for the research. All authors discussed and provided comments at all stages. All authors have read and agreed to the published version of the manuscript.

Funding: This research received no external funding.

Acknowledgments: This study is supported by CIAS Research Center for pollution control in high sterility rooms, Department of Architecture, University of Ferrara.

Conflicts of Interest: The authors declare no conflict of interest.

\section{Appendix A}

This appendix illustrates the primary energy demand (PED) for heating, cooling and lighting of the patient room evaluated for each glazing type and lighting control strategy for the four cities considered, Milan, Bologna, Rome and Naples. The findings were used to identify the percentage change in primary energy demand and the achievable energy savings presented in Tables 7-10 and in Figures $3-5$.

Table A1. Primary energy demand for heating, cooling and lighting evaluated for each glazing type and lighting control strategy in Milan.

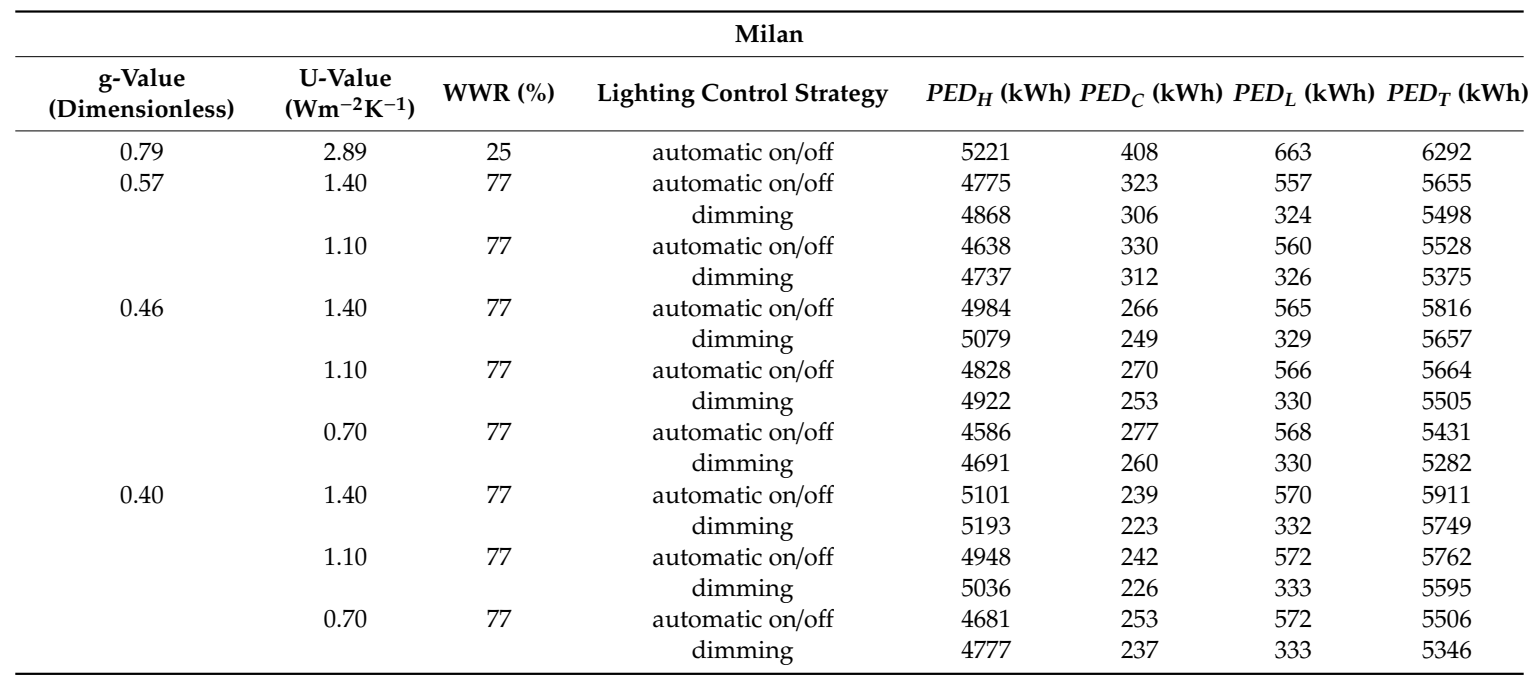


Table A2. Primary energy demand for heating, cooling and lighting evaluated for each glazing type and lighting control strategy in Bologna.

\begin{tabular}{|c|c|c|c|c|c|c|c|}
\hline \multicolumn{8}{|c|}{ Bologna } \\
\hline $\begin{array}{c}\text { g-Value } \\
\text { (Dimensionless) }\end{array}$ & $\begin{array}{c}\text { U-Value } \\
\left(\mathrm{Wm}^{-2} \mathrm{~K}^{-1}\right)\end{array}$ & WWR (\%) & Lighting Control Strategy & $P E D_{H}(\mathrm{kWh})$ & $P E D_{C}(\mathrm{kWh})$ & $P E D_{L}(\mathrm{kWh})$ & $P E D_{T}(\mathrm{kWh})$ \\
\hline \multirow[t]{3}{*}{0.57} & 1.40 & 77 & automatic on/off & 3917 & 330 & 562 & 4808 \\
\hline & & & dimming & 4101 & 313 & 329 & 4,743 \\
\hline & 1.10 & 77 & automatic on/off & 3800 & 336 & 564 & 4701 \\
\hline \multirow{5}{*}{0.46} & & & dimming & 4279 & 256 & 334 & 4869 \\
\hline & 1.10 & 77 & automatic on/off & 3954 & 276 & 571 & 4801 \\
\hline & & & dimming & 4145 & 260 & 334 & 4739 \\
\hline & 0.70 & 77 & automatic on/off & 3756 & 283 & 572 & 4612 \\
\hline & & & dimming & 3952 & 267 & 335 & 4554 \\
\hline \multirow[t]{2}{*}{0.40} & 1.40 & 77 & automatic on/off & 4180 & 245 & 575 & 5001 \\
\hline & & & dimming & 4024 & 243 & 337 & 4604 \\
\hline
\end{tabular}

Table A3. Primary energy demand for heating, cooling and lighting evaluated for each glazing type and lighting control strategy in Rome.

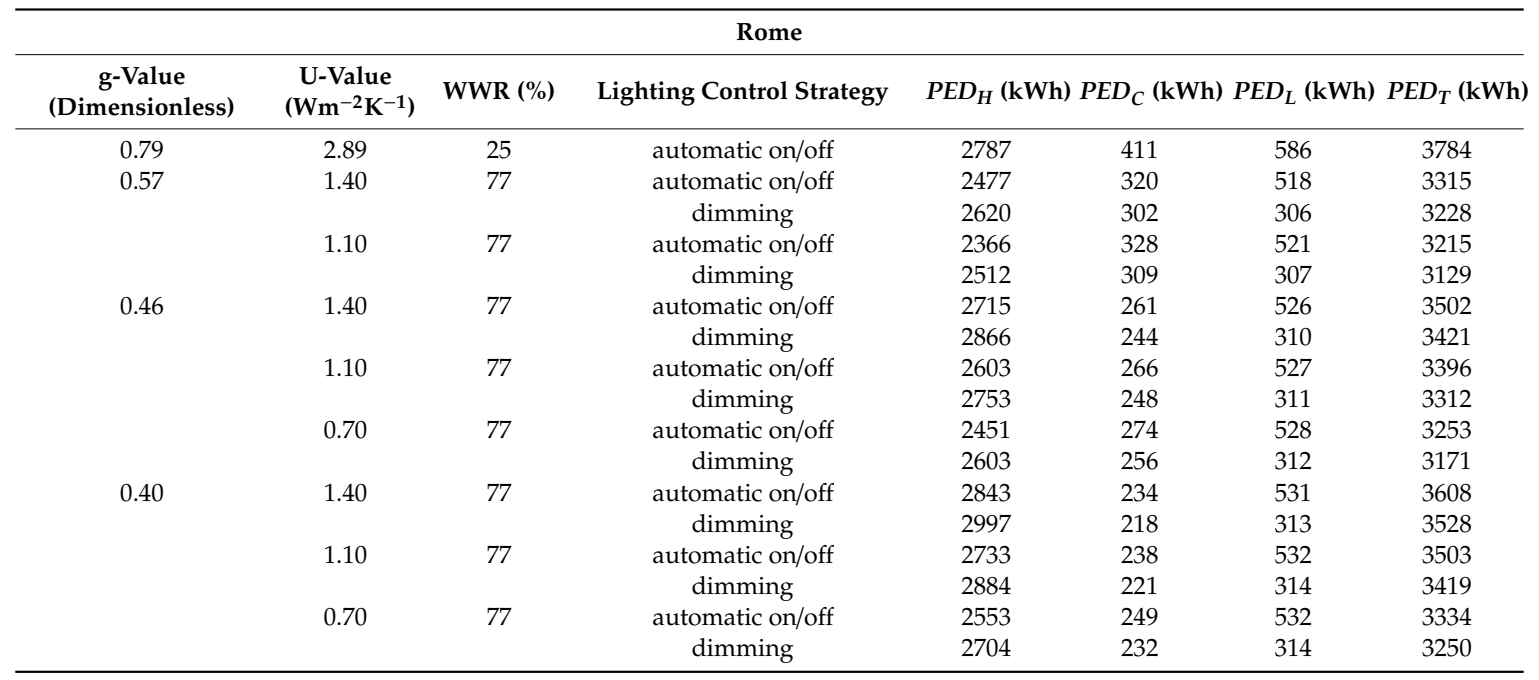


Table A4. Primary energy demand for heating, cooling and lighting evaluated for each glazing type and lighting control strategy in Naples.

\begin{tabular}{|c|c|c|c|c|c|c|c|}
\hline \multicolumn{8}{|c|}{ Naples } \\
\hline $\begin{array}{c}\text { g-Value } \\
\text { (Dimensionless) }\end{array}$ & $\begin{array}{c}\text { U-Value } \\
\left(\mathrm{Wm}^{-2} \mathrm{~K}^{-1}\right)\end{array}$ & WWR (\%) & Lighting Control Strategy & $P E D_{H}(\mathrm{kWh})$ & $P E D_{C}(\mathrm{kWh})$ & $P E D_{L}(\mathrm{kWh})$ & $P E D_{T}(\mathrm{kWh})$ \\
\hline \multirow[t]{3}{*}{0.57} & 1.40 & 77 & automatic on/off & 2166 & 360 & 520 & 3047 \\
\hline & & & dimming & 2306 & 339 & 310 & 2955 \\
\hline & 1.10 & 77 & automatic on/off & 2064 & 369 & 523 & 2956 \\
\hline \multirow{5}{*}{0.46} & & & dimming & 2525 & 276 & 315 & 3116 \\
\hline & 1.10 & 77 & automatic on/off & 2276 & 302 & 529 & 3107 \\
\hline & & & dimming & 2423 & 281 & 316 & 3020 \\
\hline & 0.70 & 77 & automatic on/off & 2139 & 311 & 530 & 2980 \\
\hline & & & dimming & 2288 & 290 & 316 & 2895 \\
\hline \multirow[t]{2}{*}{0.40} & 1.40 & 77 & automatic on/off & 2489 & 267 & 533 & 3289 \\
\hline & & & dimming & 2379 & 264 & 319 & 2962 \\
\hline
\end{tabular}

\section{References}

1. Agenzia Nazionale per i Servizi Sanitari Regionali. Principi Guida Tecnici, Organizzativi e Gestionali per la Realizzazione e Gestione di Ospedali ad Alta Tecnologia e Assistenza. Rapporto Conclusivo del Progetto di Ricerca Finalizzata (ex art. 12, dlgs 502/92). I Supplementi di Monitor; Agenzia Nazionale per i Servizi Sanitari Regionali: Rome, Italy, 2003; Volume 6.

2. Setola, N. Percorsi, Flussie Persone Nella Progettazione Ospedaliera: L'Analisi Configurazionale, Teoria e Applicazione; Firenze University Press: Florence, Italy, 2013; ISBN 978-88-6655-384-7.

3. Palumbo, R. Metaprogettazione per L'edilizia Ospedaliera; BE-MA: Milan, Italy, 1993; ISBN 887-143-141-3.

4. Rossi Prodi, F.; Stocchetti, A. L'Architettura dell'Ospedale; Alinea: Florence, Italy, 1990.

5. Enciclopedia Medica Italiana, 2nd ed.; USES: Florence, Italy, 1983; Volume 10, ISBN 88-03-00144-1.

6. Coccagna, M.; Cesari, S.; Valdiserri, P.; Romio, P.; Mazzacane, S. Impact of morphological and functional features on hospitals' energy consumption: A comparative analysis of six case studies. WSEAS Trans. Environ. Dev. 2018, 14, 212-225.

7. Ecofys. Panorama of the European Non-Residential Construction Sector. 2011. Available online: https: //leonardo-energy.pl/wp-content/uploads/2018/03/Europejski-sektor-budownictwa-niemieszkalnego.pdf (accessed on 30 December 2019).

8. Ministero Della Salute, Direzione Generale della Digitalizzazione, del Sistema Informativo Sanitario e della Statistica. Elenco delle Strutture di Ricovero Attive al 30 dicembre 2016. 2017. Available online: http://www.salute.gov.it/portale/documentazione/p6_2_8_1_1.jsp?id=13 (accessed on 8 January 2020).

9. American Society of Heating, Refrigerating and Air-Conditioning Engineers. Advanced Energy Design Guide for Large Hospitals. Achieving 50\% Energy Savings Toward a Net Zero Energy Building; ASHRAE: Atlanta, GA, USA, 2012.

10. Devlin, A.S.; Arneill, A.B. Health care environments and patient outcomes: A review of the literature. Environ. Behav. 2003, 35, 665-694. [CrossRef]

11. Dalke, H.; Littlefair, P.J.; Loe, D.; Estates, N. Lighting and Colour for Hospital Design: A Report on an NHS Estates Funded Research Project; The Stationery Office: Norwich, UK, 2004; ISBN 0-11-322491-5.

12. Verderber, S.; Reuman, D. Windows, views, and health status in hospital therapeutic environments. J. Archit. Plan. Res. 1987, 4, 120-133.

13. Douglas, C.H.; Douglas, M.R. Patient-friendly hospital environments: Exploring the patients' perspective. Health Expect. 2004, 7, 61-73. [CrossRef]

14. Verderber, S. Designing for the therapeutic functions of windows in the hospital rehabilitation environment. In Knowledge for Design, 1982 Conference of the Environmental Design Research Association, 1982; Bart, P., Chen, A., Francescato, G., Eds.; Environmental Design Research Association: College Park, MD, USA, 1982; pp. $476-492$. 
15. Verderber, S. Dimensions of person-window transactions in the hospital environment. Environ. Behav. 1986, 18, 450-466. [CrossRef]

16. Wilson, L.M. Intensive care delirium: The effect of outside deprivation in a windowless unit. Arch. Intern. Med. 1972, 130, 225-226. [CrossRef] [PubMed]

17. Schweitzer, M.; Gilpin, L.; Frampton, S. Healing spaces: Elements of environmental design that make an impact on health. J. Altern. Complement. Med. 2004, 10, S71-S83. [CrossRef]

18. Walch, J.M.; Rabin, B.S.; Day, R.; Williams, J.N.; Choi, K.; Kang, J.D. The effect of sunlight on postoperative analgesic medication use: A prospective study of patients undergoing spinal surgery. Psychosom. Med. 2005, 67, 156-163. [CrossRef]

19. Ernberg, M.; Hedenberg-Magnusson, B.; Alstergren, P.; Kopp, S. The level of serotonin in the superficial masseter muscle in relation to local pain and allodynia. Life Sci. 1999, 65, 313-325. [CrossRef]

20. Shinchuk, L.M.; Holick, M.F. Vitamin D and rehabilitation: Improving functional outcomes. Nutr. Clin. Pract. 2007, 22, 297-304. [CrossRef]

21. Ulrich, R.S. View through a window may influence recovery from surgery. Science 1984, 224, $420-421$. [CrossRef] [PubMed]

22. Beauchemin, K.; Hays, P. Dying in the myocardial in the dark: Sunshine, gender and outcomes in infarction. J. Roy. Soc. Med. 1998, 91, 352-354. [CrossRef] [PubMed]

23. Partonen, T.; Lonnqvist, J. Bright light improves vitality and alleviates distress in healthy people. J. Affect. Disorders 2000, 57, 55-61. [CrossRef]

24. Yamada, N.; Martin-Iverson, M.T.; Daimon, K.; Tsujimoto, T.; Takahashi, S. Clinical and chronobiological effects of light therapy on nonseasonal affective disorders. Biol. Psychiat. 1995, 37, 866-873. [CrossRef]

25. Golden, R.N.; Gaynes, B.N.; Ekstrom, R.D.; Hamer, R.M.; Jacobsen, F.M.; Suppes, T.; Wisner, K.L.; Nemeroff, C.B. The efficacy of light therapy in the treatment of mood disorders: A review and meta-analysis of the evidence. Am. J. Psychiat. 2005, 162, 656-662. [CrossRef]

26. Oren, D.A.; Wisner, K.L.; Spinelli, M.; Epperson, C.N.; Peindl, K.S.; Terman, J.S.; Terman, M. An open trial of morning light therapy for treatment of antepartum depression. Am. J. Psychiat. 2002, 159, 666-669. [CrossRef]

27. Terman, J.S.; Terman, M.; Lo, E.S.; Cooper, T.B. Circadian time of morning light administration and therapeutic response in winter depression. Arch. Gen. Psychiat. 2001, 58, 69-75. [CrossRef]

28. Lefkowitz, E.S.; Garland, C.F. Sunlight, vitamin D, and ovarian-cancer mortality-rates in US women. Int. J. Epidemiol 1994, 23, 1133-1136. [CrossRef]

29. Freedman, D.M.; Dosemeci, M.; McGlynn, K. Sunlight and mortality from breast, ovarian, colon, prostate, and non-melanoma skin cancer: A composite death certificate based case-control study. Occup. Environ. Med. 2002, 59, 257-262. [CrossRef]

30. Chaudhury, H.; Mahmood, A.; Valente, M. The effect of environmental design on reducing nursing errors and increasing efficiency in acute care settings: A review and analysis of the literature. Environ. Behav. 2009, 41, 755-786. [CrossRef]

31. Alimoglu, M.; Donmez, L. Daylight exposure and the other predictors of burnout among nurses in a University Hospital. Int. J. Nurs. Stud. 2005, 42, 549-555. [CrossRef] [PubMed]

32. Beauchemin, K.; Hays, P. Sunny hospital rooms expedite recovery from severe and refractory depressions. J. Affect. Disorders 1996, 40, 49-51. [CrossRef]

33. Choi, J.; Beltran, L.; Kim, H. Impacts of indoor daylight environments on patient average length of stay (ALOS) in a healthcare facility. Build. Environ. 2012, 50, 65-75. [CrossRef]

34. Benedetti, F.; Colombo, C.; Barbini, B.; Campori, E.; Smeraldi, E. Morning sunlight reduces length of hospitalization in bipolar depression. J. Affect. Disorders 2001, 62, 221-223. [CrossRef]

35. Ministero della Salute. Decreto 18 October 2012. Remunerazione Prestazioni di Assistenza Ospedaliera per Acuti, Assistenza Ospedaliera di Riabilitazione e di Lungodegenza Post Acuzie e di Assistenza Specialistica Ambulatoriale, Allegato 1, G.U. Serie Generale n.23 del 28-1-2013 - Suppl. Ordinario n. 8; Ministero della Salute: Rome, Italy, 2013.

36. The World Bank. Current Health Expenditure (\% of GDP). 2016. Available online: https://data.worldbank. org/indicator/SH.XPD.CHEX.GD.ZS (accessed on 23 April 2020).

37. Leather, P.; Pyrgas, M.; Beale, D.; Lawrence, C. Windows in the workplace: Sunlight, view, and occupational stress. Environ. Behav. 1998, 30, 739-762. [CrossRef] 
38. Finnegan, M.C.; Solomon, L.Z. Work attitudes in windowed vs. windowless environments. J. Soc. Psychol. 1981, 115, 291-292. [CrossRef]

39. Begemann, S.H.A.; Van Den Beld, G.J.; Tenner, A.D. Daylight, artificial light and people in an office environment, overview of visual and biological responses. Int. J. Ind. Ergonom. 1997, 20, 231-239. [CrossRef]

40. Galasiu, A.D.; Veitch, J.A. Occupant preferences and satisfaction with the luminous environment and control systems in daylit offices: A literature review. Energy Build. 2006, 38, 728-742. [CrossRef]

41. Christoffersen, J.; Petersen, E.; Johnsen, K.; Valbjoern, O.; Hygge, S. Windows and daylight. A post-occupancy evaluation of Danish offices. In Lighting 2000. CIBSE/ILE Joint Conference, University of York 9-11 July 2000. Conference Papers, 2000; Chartered Institution of Building Services Engineers: York, UK, 2000.

42. Keighley, E.C. Visual requirements and reduced fenestration in offices-A study of multiple apertures and window area. Build. Sci. 1973, 8, 321-331. [CrossRef]

43. Küller, R.; Lindsten, C. Health and behavior of children in classrooms with and without windows. J. Environ. Psychol. 1992, 12, 305-317. [CrossRef]

44. Heschong, L.; Wright, R.L.; Okura, S. Daylighting impacts on human performance in school. J. Illum. Eng. Soc. 2002, 31, 101-114. [CrossRef]

45. Keep, P.J. Stimulus deprivation in windowless rooms. Anaesthesia 1977, 32, 598-600. [CrossRef]

46. Lee, J.W.; Jung, H.J.; Park, J.Y.; Lee, J.B.; Yoon, Y. Optimization of building window system in Asian regions by analysing solar heat gain and daylighting elements. Renew. Energ. 2013, 50, 522-531. [CrossRef]

47. Singh, M.C.; Garg, S.N. Energy rating of different glazings for Indian climates. Energy 2009, 34, $1986-1992$. [CrossRef]

48. Persson, M.L.; Roos, A.; Wall, M. Influence of window size on the energy balance of low energy houses. Energy Build. 2006, 38, 181-188. [CrossRef]

49. Bojic, M.; Yik, F.; Sat, P. Energy performance of windows in high-rise residential buildings in Hong Kong. Energy Build. 2002, 34, 71-82. [CrossRef]

50. Gasparella, A.; Pernigotto, G.; Cappelletti, F.; Romagnoni, P.; Baggio, P. Analysis and modelling of window and glazing systems energy performance for a well insulated residential building. Energy Build. 2011, 43, 1030-1037. [CrossRef]

51. Yang, Q.; Liu, M.; Shu, C.; Mmereki, D.; Hossain, U.; Zhan, X. Impact analysis of window-wall ratio on heating and cooling energy consumption of residential buildings in hot summer and cold winter zone in China. J. Eng. 2015, 17. [CrossRef]

52. Buratti, C.; Moretti, E.; Belloni, E.; Cotana, F. Unsteady simulation of energy performance and thermal comfort in non-residential buildings. Build. Environ. 2013, 59, 482-491. [CrossRef]

53. Poirazis, H.; Blomsterberg, Å.; Wall, M. Energy simulations for glazed office buildings in Sweden. Energy Build. 2008, 40, 1161-1170. [CrossRef]

54. Eskin, N.; Türkmen, H. Analysis of annual heating and cooling energy requirements for office buildings in different climates in Turkey. Energy Build. 2008, 40, 763-773. [CrossRef]

55. Dong, Q.; Xing, K.; Zhang, H. Artificial neural network for assessment of energy consumption and cost for cross laminated timber office building in severe cold regions. Sustainability 2017, 10, 84. [CrossRef]

56. Marino, C.; Nucara, A.; Pietrafesa, M. Does window-to-wall ratio have a significant effect on the energy consumption of buildings? A parametric analysis in Italian climate conditions. J. Build. Eng. 2017, 13, 169-183. [CrossRef]

57. Goia, F.; Haase, M.; Perino, M. Optimizing the configuration of a façade module for office buildings by means of integrated thermal and lighting simulations in a total energy perspective. Appl. Energy 2013, 108, 515-527. [CrossRef]

58. Alibaba, H. Determination of optimum window to external wall ratio for offices in a hot and humid climate. Sustainability 2016, 8, 187. [CrossRef]

59. Sarbu, I.; Sebarchievici, C. Aspects of indoor environmental quality assessment in buildings. Energy Build. 2013, 60, 410-419. [CrossRef]

60. EFEN, Design Builder Software. Available online: http://www.designbuildersoftware.com/efen.php (accessed on 23 April 2020). 
61. Windows and Daylighting Group, Environmental Energy Technologies Department, Lawrence Berkeley National Laboratory. COMFEN 5, for Calculating the Energy Demand and Comfort Impacts of Windows in Commercial Buildings, 2019. Windows and Daylighting - Berkeley Lab Web Site. Available online: https://windows.lbl.gov/sites/default/files/software/COMFEN/COMFEN5UserManual.pdf (accessed on 23 April 2020).

62. MIT Design Advisor. Available online: http://designadvisor.mit.edu/design/ (accessed on 23 April 2020).

63. Cesari, S.; Valdiserri, P.; Coccagna, M.; Mazzacane, S. Energy savings in hospital patient rooms: The role of windows size and glazing properties. Enrgy. Proced. 2018, 148, 1151-1158. [CrossRef]

64. Hensen, J.L.M.; Lamberts, R. Building Performance Simulation for Design and Operation; Spon Press: London, UK, 2012; ISBN 978-04-1547-414-6.

65. Lodi, C.; Magli, S.; Contini, F.M.; Muscio, A.; Tartarini, P. Improvement of thermal comfort and energy efficiency in historical and monumental buildings by means of localized heating based on non-invasive electric radiant panels. Appl. Therm. Eng. 2017, 126, 276-289. [CrossRef]

66. Sarbu, I.; Sebarchievici, C. Performance evaluation of radiator and radiant floor heating systems for an office room connected to a ground-coupled heat pump. Energies 2016, 9, 228. [CrossRef]

67. Loreti, L.; Valdiserri, P.; Garai, M. Dynamic simulation on energy performance of a school. Energy Proc. 2016, 101, 1026-1033. [CrossRef]

68. Magli, S.; Lodi, C.; Contini, F.M.; Muscio, A.; Tartarini, P. Dynamic analysis of the heat released by tertiary buildings and the effects of urban heat island mitigation strategies. Energy Build. 2016, 114, 164-172. [CrossRef]

69. Stojiljkovic, M.M.; Ignjatovic, M.G.; Vuckovic, G.D. Greenhouse gases emission assessment in residential sector through buildings simulations and operation optimization. Energy 2015, 92, 420-434. [CrossRef]

70. Sajjadian, S.M. Risk identification in the early design stage using thermal simulations—A case study. Sustainability 2018, 10, 262. [CrossRef]

71. Valdiserri, P. Evaluation and control of thermal losses and solar fraction in a hot water solar system. Int. J. Low Carbon Technol. 2018, 13, 260-265. [CrossRef]

72. You, W.; Ding, W. Building façade opening evaluation using integrated energy simulation and automatic generation programs. Arch. Sci. Rev. 2015, 58, 205-220. [CrossRef]

73. Energy Performance of Buildings-Part. 1: Evaluation of Energy Need for Space Heating and Cooling; UNI/TS 11300-1:2014; Italian Organization for Standardization: Milan, Italy, 2014.

74. Klein, S.A.; Beckman, W.A.; Mitchell, J.W.; Duffie, J.A.; Duffie, N.A.; Freeman, T.L.; Mitchell, J.C.; Braun, J.E.; Evans, B.L.; Kummer, J.P.; et al. TRNSYS Version. 18; Solar Energy Laboratory, University of Wisconsin-Madison: Madison, WI, USA, 2018.

75. Athienitis, A.; O'Brien, W. Modeling, Design, and Optimization of Net-Zero Energy Buildings; Ernst \& Sohn: Berlin, Germany, 2015; ISBN 978-3-433-03083-7.

76. Kottek, M.; Grieser, J.; Beck, C.; Rudolf, B.; Rubel, F. World map of the Köppen-Geiger climate classification updated. Meteorol. Z. 2006, 15, 259-263. [CrossRef]

77. Heating and Cooling of Buildings. Climatic Data-Part. 3: Accumulated Temperature Differences (Degree-Days) and Other Indices; UNI EN ISO 10349-3:2016; Italian Organization for Standardization: Milan, Italy, 2016.

78. ENEA, Atlante Italiano della Radiazione Solare. Average Global Solar Radiation on the Horizontal Plane. Available online: http://www.solaritaly.enea.it/CalcComune/Calcola.php (accessed on 12 May 2019).

79. Terrinoni, L.; Signoretti, P.; Iatauro, D. Indice di Severità Climatica: Classificazione dei Comuni Italiani ai Fini della Climatizzazione Estiva Degli Edifici, 2012. ENEA Web Site. Available online: http://www.enea.it/it/Ricerca_sviluppo/documenti/ricerca-di-sistema-elettrico/risparmioenergia-settore-civile/2011/107-rds-pdf (accessed on 15 January 2020).

80. Terrinoni, L.; Signoretti, P.; Iatauro, D.; Romeo, C.; Federici, A. Prima Applicazione Dell'indice di Severità Climatica "All Weather" per la Definizione delle Zone Climatiche dell'Italia per la Regolamentazione dei Consumi Energetici Derivanti dalla Climatizzazione Estiva Degli Edifici, 2010. ENEA Web Site. Available online: http://www.enea.it/it/Ricerca_sviluppo/documenti/ricerca-di-sistema-elettrico/fabbisogni-consumienergetici/2.pdf (accessed on 15 January 2020).

81. Energy Standard for Buildings Except Low-Rise Residential Buildings; ANSI/ASHRAE/IES Standard 90.1-2016; ASHRAE: Atlanta, GA, USA, 2016. 
82. Ergonomics of the Thermal Environment-Analytical Determination and Interpretation of Thermal Comfort Using Calculation of the PMV and PPD Indices and Local Thermal Comfort Criteria; EN-ISO 7730; International Organization for Standardization: Geneva, Switzerland, 2005.

83. European Committee for Standardization. Lighting of Work Places- Part. 1: Indoor Work Places; EN 12464-1:2011; CEN: London, UK, 2011.

84. ASHRAE. Chapter 18: Nonresidential cooling and heating load calculations. In ASHRAE Handbook: Fundamentals; American Society of Heating, Refrigerating and Air-Conditioning Engineers: Atlanta, GA, USA, 2017.

85. De Rubeis, T.; Nardi, I.; Muttillo, M.; Ranieri, S.; Ambrosini, D. Room and window geometry influence for daylight harvesting maximization-Effects on energy savings in an academic classroom. Energy Proc. 2018, 148, 1090-1097. [CrossRef]

86. Li, D.H.W.; Cheung, A.C.K.; Chow, S.K.H.; Lee, E.W.M. Study of daylight data and lighting energy savings for atrium corridors with lighting dimming controls. Energy Build. 2014, 72, 457-464. [CrossRef]

87. Li, D.H.W.; Cheung, K.L.; Wong, S.L.; Lam, T.N.T. An analysis of energy-efficient light fittings and lighting controls. Appl. Energy 2010, 87, 558-567. [CrossRef]

88. Li, D.H.W.; Lam, J.C. Evaluation of lighting performance in office buildings with daylighting controls. Energy Build. 2001, 33, 793-803. [CrossRef]

89. Li, D.H.W.; Lam, T.N.T.; Wong, S.L. Lighting and energy performance for an office using high frequency dimming controls. Energy Conv. Manag. 2006, 47, 1133-1145. [CrossRef]

90. Doulos, L.; Tsangrassoulis, A.; Topalis, F. Quantifying energy savings in daylight responsive systems: The role of dimming electronic ballasts. Energy Build. 2008, 40, 36-50. [CrossRef]

91. Nielsen, M.V.; Svendsen, S.; Jensen, L.B. Quantifying the potential of automated dynamic solar shading in office buildings through integrated simulations of energy and daylight. Sol. Energy 2011, 85, 757-768. [CrossRef]

92. Tzempelikos, A.; Athienitis, A.K. The impact of shading design and control on building cooling and lighting demand. Sol. Energy 2007, 81, 369-382. [CrossRef]

93. Kerkhof, G.A.; Van Dongen, H.P.A. Human Sleep and Cognition, Volume 185; Elsevier Science: Oxford, UK, 2010; ISBN 978-0-444-53702-7.

94. Stickgold, R.; Walker, M.P. The Neuroscience of Sleep; Academic Press (Elsevier Science): London, UK, 2009; ISBN 978-0-12-375073-0.

95. Bes, F.; Jobert, M.; Schulz, H. Modeling napping, post-lunch dip, and other variations in human sleep propensity. SLEEP 2009, 32, 392-398. [CrossRef]

96. Horne, J.; Reyner, L. Vehicle accidents related to sleep: A review. Occup. Environ. Med. 1999, 56, $289-294$. [CrossRef]

97. Broughton, R.J. SCN Controlled circadian arousal and the afternoon "nap zone". Sleep Res. Online 1998, 1, 166-178.

98. Broughton, R.J. Chronobiological aspects and models of sleep and napping. In Sleep and Alertness: Chronobiological, Behavioural, and Medical Aspects of Napping; Dinges, D.F., Broughton, R.J., Eds.; Raven Press: New York, NY, USA, 1989; pp. 71-98. ISBN 978-0-881-67524-5.

99. Lack, L.; Lushington, K. The rhythms of human sleep propensity and core body temperature. J. Sleep Res. 1996, 5, 1-11. [CrossRef]

100. Ministry of Economic Development, D.M. 26/06/2015: Applicazione delle Metodologie di Calcolo delle Prestazioni Energetiche e Definizione delle Prescrizioni e dei Requisiti Minimi Degli Edifici, Supplemento Ordinario n. 39. Gazzetta Ufficiale 2015, 162.

101. Criteri di Sicurezza nelle Applicazioni Vetrarie; UNI 7697:2015; Italian Organization for Standardization: Milan, Italy, 2015.

102. Decree of the President of the Council of Ministers (DPCM) 5 December 1997. Determination of passive acoustic requirements of buildings. Gazzetta Ufficiale Serie Generale n.297 del 22-12-1997; Istituto Poligrafico e Zecca dello Stato: Rome, Italy, 1997. (In Italian)

103. Glass in Building-Pendulum Test.-Impact Test. Method and Classification for Flat Glass; UNI EN 12600:2004; CEN: Brussels, Belgium, 2004. 
104. Windows and Daylighting Group, Environmental Energy Technologies Department, Lawrence Berkeley National Laboratory. WINDOW 7 User Manual, 2019. Windows and Daylighting - Berkeley Lab Web Site. Available online: https://windows.lbl.gov/sites/default/files/software/WINDOW/WINDOW7UserManual.pdf (accessed on 23 April 2020).

105. American Society of Heating, Refrigerating and Air-Conditioning Engineers. Standard Method for Determining and Expressing the Heat Transfer and Total Optical Properties of Fenestration Products, Public Review Draft of Standard 142; ASHRAE: Atlanta, GA, USA, 1998.

106. Thermal Performance of Windows, Doors and Shading Devices-Detailed Calculations; ISO 15099; International Organization for Standardization: Geneva, Switzerland, 2003.

107. Biserni, C.; Valdiserri, P.; D'Orazio, D.; Garai, M. Energy retrofitting strategies and economic assessments: the case study of a residential complex using utility bills. Energies 2018, 11, 2055. [CrossRef]

108. Repubblica Italiana. Gazzetta Ufficiale Serie Generale n.100 del 29-04-2008; Istituto Poligrafico e Zecca dello Stato: Rome, Italy, 2008. (In Italian)

109. Gimelli, A.; Muccillo, M. The key role of the vector optimization algorithm and robust design approach for the design of polygeneration systems. Energies 2018, 11, 821. [CrossRef]

110. Noro, M.; Lazzarin, R.; Busato, F. Multisource heat pump system: The case study of a new school building. In Progress in Sustainable Energy Technologies Vol II, Creating Sustainable Development; Dincer, I., Midilli, A., Kucuk, H., Eds.; Springer International Publishing: Cham, Switzerland, 2014; Volume 2, pp. 591-607.

111. Marrasso, E.; Roselli, C.; Sasso, M. Electric efficiency indicators and carbon dioxide emission factors for power generation by fossil and renewable energy sources on hourly basis. Energ. Convers. Manag. 2019, 196, 1369-1384. [CrossRef]

112. Asdrubali, F.; Baggio, P.; Prada, A.; Grazieschi, G.; Guattari, C. Dynamic life cycle assessment modelling of a NZEB building. Energy 2020, 191, 116489. [CrossRef]

113. Istituto Superiore per la Protezione e la Ricerca Ambientale (ISPRA). Tabella dei Parametri Standard Nazionali per il Monitoraggio e la Comunicazione dei Gas ad Effetto Serra ai Sensi del Decreto Legislativo n.30 del 2013. Available online: https://www.minambiente.it/sites/default/files/archivio/allegati/emission_trading/ tabella_coefficienti_standard_nazionali_11022019.pdf (accessed on 18 April 2020). (In Italian).

114. Environmental Sustainability of Construction Works-Operational Tools for Sustainability Assessment-Residential Buildings; UNI/PdR 13.2:2019.; Italian Organization for Standardization: Milan, Italy, 2019.

115. Pichler, P.P.; Jaccard, I.S.; Weisz, U.; Weisz, H. International comparison of health care carbon footprints. Environ. Res. Lett. 2019, 14. [CrossRef] 